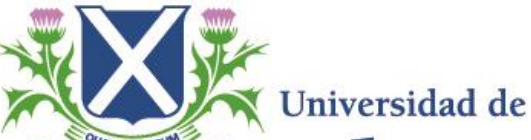 SanAndrés
}

"Career Choices and the Evolution of the College Gender Gap"

Por Martín Rossi (Universidad de San Andrés) y Christian Ruzzier (Universidad de San Andrés).

D.T.: $\mathbf{N}^{\circ} 120$

Marzo 2015

Vito Dumas 284, B1644BID, Victoria, San Fernando, Buenos Aires, Argentina Teléfono 4725-7020, Fax 4725-7010

Email: economia@udesa.edu.ar 


\title{
Career Choices and the Evolution of the College
}

\author{
Gender Gap
}

\author{
Martín A. Rossi and Christian A. Ruzzier*
}

February 16, 2015

\begin{abstract}
We propose a complementary explanation for the evolution of the college gender gap that emphasizes the raising opportunity cost of pursuing a college degree for men, due to the increase in the rewards to becoming a superstar in men-dominated occupations, like professional sports. We support our explanation with causal evidence from a natural experiment in European soccer markets that provides exogenous variation in male earnings in a superstar path. Consistent with our story, we find a significant positive effect of an increase in male superstar earnings on the ratio of female to male tertiary enrollment in college education.
\end{abstract}

JEL Codes: I20, J16, J24.

Keywords: gender gap, superstars, education.

*Rossi: Department of Economics, Universidad de San Andrés, Vito Dumas 284, B1644BID Victoria, Buenos Aires, Argentina (e-mail: mrossi@udesa.edu.ar); Ruzzier: Department of Economics, Universidad de San Andrés, Vito Dumas 284, B1644BID Victoria, Buenos Aires, Argentina (e-mail: cruzzier@udesa.edu.ar). 


\section{Introduction}

It is a well-documented fact that women have been catching up with men in terms of educational achievement, and have actually overtaken them in many countries. Figure 1 plots the recent evolution of the average ratio of female to male tertiary enrollment for 147 countries from all over the world, and shows a clear upward trend in female college enrollments relative to male enrollments, with women catching up with men in the early 1990s, and consistently overperforming them in terms of college attendance ever since.

\section{[FIGURE 1 ABOUT HERE]}

As Goldin, Katz, and Kuziemko (2006, p. 153) point out, the puzzle here is "[w]hy have females surpassed males in college going and college completion and not simply caught up to them." Several explanations to this puzzle have been advanced. ${ }^{1}$ For instance, changes in social norms and expectations about the roles of work, marriage, and motherhood for women plus greater protection for gender equality at work and the introduction of the pill, allowed greater participation of women in higher education (Goldin and Katz, 2002; Goldin, Katz, and Kuziemko, 2006). As argued in Goldin (2004), the fact that it is now easier to combine having a family and a career also encourages female participation. Incidentally, the largest gender gap among OECD countries is found in Scandinavian countries, the first to achieve this family-career balance (Vincent-Lancrin, 2008).

The decline in the within-family discrimination against girls may have also played a role. As explained in Buchmann and DiPrete (2006), the higher the parents' level of education and economic resources, the more likely they are to be relatively gender-neutral in their investments in education. According to this explanation, secular increases in education and income would tend to improve female relative college outcomes. ${ }^{2}$ Moreover, exogenous changes in labor markets favoring women have led many parents to have higher educational expectations for their 
daughters than for their sons (Chen et al., 2011), which might provide additional incentives for girls if, as argued by psychologists, girls deem pleasing adults more important than boys do (Fortin, Oreopoulos, and Phipps, 2013). Finally, decreases in family size may have also increased female college-going if, as evidence (Averett and Burton, 1996; Ono, 2004; Tansel, 2002) shows, the larger the family, the smaller the chance of girls of going to college.

In and of themselves, the previous demographic and sociological explanations can explain why women have caught up to men once barriers to female participation were removed, but are less well suited to explain the reversal of the gender gap. Explanations based on economic factors, like changes in the returns to higher education, seem more promising: if the returns to attending college increased more for women than for men, reversal could be explained (as long as women and men respond equally to the wage premium). Evidence of such a relative change in returns can be found in Dougherty (2005) and Fortin (2006) for the United States, although evidence for other countries is scarce (Vincent-Lancrin, 2008). The change is larger when considering a broader definition of returns (including the probability of getting and staying married, and of avoiding poverty), as in DiPrete and Buchmann (2006), since women graduates are less likely to be the head of a single-parent household and work part-time, and hence less likely to be poor.

Educational factors may also explain the reversal in the college gender gap. In particular, girls have been improving their academic preparation relative to boys over the past few decades, and this investment appears to be driven by economic (increase in women's returns to higher education) and demographic (increase in the age at first marriage) factors (see Goldin, Katz, and Kuziemko, 2006). Besides, women have greater aspirations than men, and aspirations have risen more rapidly for women (McDaniel, 2007; Goldin, Katz, and Kuziemko, 2006). As shown in Fortin, Oreopoulos, and Phipps (2013), gender differences in post-secondary expectations are the most important factor accounting for the disparities in academic 
achievement in high school.

To sum up, many plausible explanations have been given for the evolution of the college gender gap in recent decades. In this paper we propose a complementary explanation that has been largely overlooked in the literature: the increase in men's opportunity cost of attending college due to an increase in their returns to becoming a superstar. We then provide causal evidence in support of our explanation from a natural experiment in a prominent superstar path, professional sports, in which the compensation gap grossly favors men.

Individuals may refrain from going to college because the labor market returns are too low or because the costs associated to college-going are too high. For many individuals, the opportunity costs of their time loom large amongst the costs of attending college. For some individuals, pursuing a superstar career (e.g., professional sports) might be the best alternative to investing in their human capital. ${ }^{3}$ An increase in the return of becoming a superstar would increase the opportunity cost of pursuing college studies for these individuals. Under the premise that superstar returns increase relatively more for men, we would predict that men are more likely to stay longer in the superstar path to the detriment of their accumulation of human capital (say, by engaging sports rather than enrolling in college). ${ }^{4}$ Thus, we should observe that an increase in superstar earnings for men leads to an increase in the ratio of female to male enrollment in college.

Athlete superstars are mostly men. Nowadays, the best-paid athlete superstar in each of the 182 countries for which the information is available is a man, and 97 of the world's 100 highest-paid athletes are men. ${ }^{5}$ The fact that becoming an athlete superstar is more appealing for men is not new. ${ }^{6}$ According to Forbes Magazine, in every year from 1990 to 2013 the top 10 paid athletes have been men (only one woman, tennis player Monica Seles, appeared 10th in 1992). ${ }^{7}$

For the last 40 years the relative salary of superstar athletes has been increasing dramatically, thus raising the opportunity cost of schooling. As an example, Figure 
2 documents the evolution of weekly salaries in baseball relative to the weekly earnings of production workers in the United States in the period 1970-2011. Given that superstar athletes are mostly men, rather than women, we claim that this different increase in the opportunity cost of attending college can help explain the observed trends in the college gender gap depicted in Figure 1.

\section{[FIGURE 2 ABOUT HERE]}

We exploit changes in European soccer markets as a source of exogenous variation in men's opportunity cost of pursuing college studies. European soccer markets provide an ideal setting. Soccer is the most popular sport in the world and it is male-dominated: according to a 2006 FIFA (Fédération Internationale de Football Association, the world governing body of soccer) census of its 207 member associations, $90 \%$ of soccer players and all professional players were men. Professional players in the top European soccer leagues are among the highest paid athletes in the world, and top leagues employ an increasing fraction of players from all over the world. These features of the European soccer market can be seen, to a great extent, as consequences of the Bosman ruling, a European Court of Justice judgment in 1995 that established free agency and abolished existing limitations on the nationality of players. Whereas free agency shifted bargaining power from clubs to players, and resulted in a marked increase in wages for every professional player in a top European league, exposure to such a wage increase depended on the perceived chances of making it to those leagues, which vary strongly across countries. We exploit this cross-country variation in the exposure to the Bosman ruling to identify the impact of a change in men's opportunity cost of pursuing college studies on college enrollment.

Since the shock to the returns to becoming a superstar might indirectly affect other determinants of human capital decisions, its total effect on male enrollment is uncertain in our empirical setup because of these confounding factors. As long as all confounders that vary across countries and time affect in a similar way female 
and male enrollment, we can nevertheless obtain an unambiguous prediction for the effect of the shock by focusing on the ratio of female to male tertiary enrollment.

Our main finding is that an increase of one standard deviation in the exposure to the Bosman ruling is associated with an increase in the ratio of female to male tertiary enrollment in the post-Bosman period of around 1.5 women for every 100 men (evaluated at the sample mean of the ratio). Assuming that all of the change in the college gender gap comes from a reduction in male enrollment, back-of-theenvelope calculations suggest it requires that 1 out of 7 potential college enrollees from the under-18 subpopulation actively involved in soccer playing (which represents only $14 \%$ of males in the relevant age group) decide not to attend college to generate the estimated effect. Results are robust to using different samples of countries, to allowing for regional time trends, and to exploiting alternative definitions of exposure.

Our paper is related to a recent and growing literature studying how human capital investment decisions are affected by plausibly exogenous changes in labor market opportunities (see Bobba, Flabbi, and Levy, 2012, for a recent overview). ${ }^{8}$ Such changes may affect labor market returns, thus altering the benefit of investing in human capital, or as in our paper, they may affect the opportunity cost of human capital investments.

The basic prediction from economic models of human capital investment (Becker, 1967; Ben-Porath, 1967) is that increases in the perceived returns to education should lead to higher investments in education. Consistent with this view, Abramitzky and Lavy (2011) exploit the timing of changes in wage setting in Israeli kibbutzim (from setting wages independent of an individual's human capital to setting wages reflecting the market rate of return) to show how an increase in the rate of return to education lead high school students to invest more in their education. Munshi and Rosenzweig (2006), on the other hand, show how, even if the returns to learning English (the only language in college education) increased in the 1990s for both sexes 
in India, only girls have taken advantage of this improvement by switching to English schools, whereas boys' schooling choices have been constrained by caste-based historical occupations.

Heath and Mobarak (2012) find that the rapid expansion of the garment industry in Bangladesh, by providing employment opportunities to women, has increased schooling for younger girls (aged 5-10), because the new jobs require the ability to read English and do basic math, thus increasing the returns to education. Interestingly, the authors find that the effect of the arrival of garment jobs is negative for 17 and 18 year olds, because they are more likely to drop out of school to take the jobs and start earning right away - a natural choice given that the opportunity cost of schooling increases for these girls. In a similar vein, Atkin (2012) exploits variation in the timing of factory openings across municipalities in Mexico to show that the creation of low-skill export manufacturing jobs raised the opportunity cost of schooling and lead to an increase in school dropout. Our paper is close to Atkin's in that both of our papers highlight changes in the opportunity cost of schooling to explain trends in educational outcomes. In contrast, we put the focus on factors that affect the opportunity cost of schooling differentially between boys and girls. ${ }^{9}$

The remainder of the paper confronts our predictions with the data: we discuss our identification strategy in Section 2 and present our results in Section 3. Section 4 concludes.

\section{Natural experiment and data}

We propose an explanation for the evolution of the college gender gap that emphasizes the increase in men's opportunity cost of attending college due to an increase in the return of becoming a superstar athlete. To test our prediction we need data on college attendance by gender and a source of exogenous variation in the expected returns for men in a superstar path. Accordingly, in this section we describe the 
setup and data for our empirical exercise and discuss how we can exploit changes in European soccer markets as a source of exogenous variation in the expected earnings for men associated with the superstar path. ${ }^{10}$

\subsection{The natural experiment}

Soccer is indisputably the most popular sport in the world and it is played mostly by men. ${ }^{11}$ According to the 2006 Big Count, a FIFA survey of its 207 member associations, 265 million players (professional, registered, and occasional) were actively involved in this sport. Of this grand total, $90 \%$ of players were male, and only men were involved in professional play.

Professional soccer players are among the highest paid athletes of any sport in the world, and among the top 10 sports teams by average salary per player, seven are soccer clubs from Europe's Big Five leagues. ${ }^{12}$ The Big Five leagues are the German Bundesliga, Italian Serie A, Spanish Liga, English Premier League, and French Ligue 1 - these are the leagues that generate the largest revenues and pay the highest salaries. ${ }^{13}$ The highest paying team in the world is FC Barcelona (of the Spanish league) and has an average salary of $\$ 8.7$ million a year, with each player earning about $\$ 167,000$ a week.

The high salaries obtained in the Big Five leagues are hard to match outside of Europe: the average player for the Sporting Kansas City, the 2012-13 champion of America's Major League Soccer, made $\$ 106,836$ a year as base salary in 2013 , whereas minimum wages for professional players in South America are below $\$ 3,600$ a year and strikes over unpaid wages are not uncommon. ${ }^{14}$ While in 2012 top players Lionel Messi (FC Barcelona) and Cristiano Ronaldo (Real Madrid) made over $\$ 20$ million just in salary, Kansas City's top paid player, Graham Zusi, made $\$ 350,000$ in 2013, an amount the average player of FC Barcelona can earn in just two weeks. ${ }^{15}$ The landscape of European soccer salaries has not always been this bright: when soccer star Diego Maradona was transferred to FC Barcelona in 1982, his salary 
was a meagre $\$ 50,000$ a year, and in the early 1990 s the average player in England's top division made $\$ 138,000$ to $\$ 147,000$ a year. ${ }^{16}$

Soccer teams in Big Five leagues recruit talent from all over the world. At the start of the 2013-14 season, 51 percent of players in a given Big Five league were foreigners. ${ }^{17}$ In 2010, Inter Milan (from Italy's Serie A) won the UEFA (Union des Associations Européennes de Football) Champions League (Europe's top club tournament) with a typical lineup that did not include a single Italian. It is not the case, however, that foreigners have always been so present in European leagues. In 1992 only 5\% of non-British players were in the starting lineups of Premier League clubs - a number now close to $70 \% .{ }^{18}$ When Manchester United won England's Premier League in 2012-13, roughly 50\% of its team roster and typical lineup were foreigners, whereas in 1995-96 the club had achieved the same feat with just five foreigners out of a squad of 31 players (16\%), and no more than two in their typical lineup.

To a great extent, the changes in salaries and team composition can be traced back to a European Court of Justice (ECJ) judgment in December 1995 that established free agency and abolished existing limitations on the nationality of players (see, e.g., Downey, 2001; Frick, 2007; and Poli, 2006, 2010). Before the ECJ judgment, most players in a given club were national, thanks to a UEFA rule stating that no team could field more than three non-nationals at the same time. ${ }^{19}$ When a player reached the end of his contract with a club, he did not become a free agent: he could ask for a transfer to another institution, but such a transfer would only proceed provided the new club could agree on a transfer fee with the old club; else, the player would be forced to re-sign with his old club or not play for the whole season. ${ }^{20}$

These two basic principles (limits on non-nationals and transfer fees for out-ofcontract players) were challenged in court by a Belgian player, Jean-Marc Bosman, in 1990. When his contract with Belgian club RFC Liège expired, Bosman arranged 
for a transfer with Dunkerque, a French team. As both clubs could not settle on a transfer fee, RFC Liège refused to let Bosman go. The player refused to re-sign with his old club, was suspended and took his case to court. In the final judgment on the case (which became known as the Bosman ruling), the ECJ declared in December 1995 that both UEFA regulations (the transfer system and the nationality rule) were incompatible with article 48 (now article 39) of the Treaty establishing the European Union (EU), which guaranteed freedom of movement for workers. ${ }^{21}$

The resulting liberalization of the European transfer market had easily noticeable consequences for players' salaries and mobility. The abolition of the transfer fee for players out of contract meant a player would become a free agent at the expiration of his contract, and could now offer his services to the highest bidder. The free-agency regime shifted bargaining power from clubs to players, and resulted in a drastic increase in wages. ${ }^{22}$ For instance, pre-Bosman, Chris Sutton was the highest paid player in England's Premier League on a weekly salary of $£ 10,000$ in 1994 at Blackburn Rovers FC, and by 1996, Fabrizio Ravanelli was rumored to be on a salary of $£ 40,000$-a-week at Middlesbrough FC. ${ }^{23}$ More generally, Dobson and Goddard (2011) show that salary inflation in English soccer was exceptional (and well above revenue growth) during the immediate post-Bosman period, and Feess et al. (2010) document that wages experienced a discrete (upward) jump immediately after the Bosman ruling in Germany's Bundesliga. Figure 3 presents a broader picture of the evolution of the gross salary expenditure in each of the Big Five leagues from 1995/96 (the last season played under the old rules) to 2001/02. ${ }^{24}$ Salaries had doubled by 1998/99 and more than tripled by 2001/02.

\section{[FIGURE 3 ABOUT HERE]}

By abolishing nationality requirements in the composition of teams at club level, the Bosman ruling also implied that every soccer club in the EU could now field as many non-nationals as they saw fit, provided the players held a EU passport, thereby opening up a new international transfer market. To begin with, every non- 
national slot occupied by a EU citizen by the time of the ruling immediately became a vacant slot for the $1996 / 97$ season. But the ruling also markedly increased the value of holding a European passport, or obtaining one through European descent (as in the case, e.g., of Argentine players of Italian or Spanish descent) or residence (for instance, Belgium is usually considered to place the less stringent requirements to grant nationality to foreign residents). ${ }^{25}$ As Figure 4 shows, the Bosman ruling had a deep impact on the number of foreign players in Big Five leagues, as Europe's search for soccer talent became a global phenomenon. While the number of foreign players in Big Five leagues had been around 400 in previous seasons close to the Bosman ruling (and growing at an average annual rate of less than $7 \%$ ), that figure jumped to 635 in the 1996/97 season, the first under the new rules - a 35\% increase. The number of foreign players had doubled by 1998/1999 and tripled by 2007/08.

[FIGURE 4 ABOUT HERE]

\subsection{Data}

We use the ratio of total female to male enrollment in tertiary education in public and private schools (also known as the Gender Parity Index in tertiary level enrollment in the United Nations' Millennium Development Goals Indicators) as our measure of the relative accumulation of human capital by gender. ${ }^{26}$ The World Bank, through its World Development Indicators collection, provides consistent yearly data on this indicator for 214 countries from 1970 to $2011 .^{27}$ We eliminated 7 countries for implausible data, and also every country for which the database does not provide at least one observation pre-Bosman and one observation post-Bosman,

leaving us with 147 countries to work with. ${ }^{28}$ Table 1 contains summary statistics for our sample.

\section{[TABLE 1 ABOUT HERE]}

Whereas the Bosman ruling implied an increase in salaries in the superstar path only for men from any country, conditional on playing for a team in a Big Five 
league, exposure to such change depended on the perceived chances of eventually making it to those leagues - chances that vary strongly across countries, due to the quality of their players and their ease of access to a European passport. ${ }^{29}$

To assess these chances, we begin by computing for every country in our sample the number of soccer players from each country in Big Five leagues in the 1994/95 season (the last full season prior to the Bosman ruling). ${ }^{30}$ To classify a player in a Big Five league as a national or a non-national, we have used their first nationality (usually the country where the player was developed) rather than the nationality under which they are playing. ${ }^{31}$ As it is not the same, in terms of career choices and perceived chances of success in the superstar path, to see 100 fellow countrymen succeeding in Big Five leagues in a country of 1,000,000 inhabitants than in another country with a population of $100,000,000$, in the empirical exercise we divide the number of players by each country's population in $1994 .^{32}$

To convey a quick image of the countries most affected by the Bosman ruling, we have colored those countries in the world map provided in Figure 5 (the full list of countries can be found in Tabla B1 in Appendix B). Countries in black are the top 10 countries according to the number of players in Big Five soccer leagues per 1,000,000 inhabitants in 1994. Countries in the top 15 appear in blue, whereas yellow-colored countries are those in the top 30. As can be observed in Figure 5 (and Table B1), the group of countries most exposed to the Bosman ruling includes countries from Latin America and the Caribbean (like Jamaica and Uruguay), Africa (Liberia, Equatorial Guinea), and Europe. And even amongst those European countries there is substantial heterogeneity, with Nordic (e.g., Iceland and Norway), Western European (e.g., Ireland and the Netherlands), and Eastern European (e.g., Croatia and Bulgaria) countries. This suggests that the results shown below are not picking up a spurious trend in a small subset of peculiar countries. Moreover, as we discuss below, the trends in the college gender gap in more and less exposed countries are indistinguishable in the pre-Bosman period. 


\section{Econometric methods and results}

The previous section shows that the Bosman ruling increased expected earnings for young males in a group of countries by increasing both the earnings associated with the superstar path and the probability of achieving success on that path. In this section we exploit the Bosman ruling as a source of exogenous variation in the expected earnings of men in the superstar path. Our hypothesis is that an increase in the prize for men in the superstar path should lead to an increase in the ratio of female to male accumulation of human capital. We test this hypothesis by estimating the effect of the Bosman ruling on the ratio of female to male tertiary enrollment. ${ }^{33}$ Formally, we estimate the following regression model:

$$
\begin{aligned}
\ln \text { Female to male tertiary enrollment } & =\beta\left(\text { Bosman }_{t} * \text { Average player }_{i}\right) \\
& +\alpha_{i}+\mu_{t}+\varepsilon_{i t},
\end{aligned}
$$

where $\alpha_{i}$ is a time-invariant country effect, $\mu_{t}$ is a time-period effect common to all countries, and $\varepsilon_{i t}$ is the usual error term. Our main explanatory variable has variability both across time and across countries. The time variability is captured by a dummy variable that takes the value of one after $1995\left(\right.$ Bosman $\left._{t}\right)$, and the cross-country variation is captured by Average player $s_{i}$, defined as the ratio of the number of country $i$ 's players in Big Five soccer leagues to the country's population (in millions), in 1994. The parameter of interest in equation (1) is $\beta$, which captures the interaction effect between the time variability and the country variability in the prize faced by men in the superstar path. In light of the previous discussion, we expect $\beta>0$.

The use of the ratio of female to male enrollment as our dependent variable is 
central for our identification strategy, since it guarantees that all confounders that vary across countries and time, and that affect in a similar way female and male enrollment are not biasing our estimates of $\beta$.

The main empirical result of the paper is anticipated in Figure 6. The figure compares the evolution of the average ratio of female to male tertiary enrollment for countries that are more exposed to the Bosman ruling relative to the rest of the countries in the subsample of countries with ratios above the sample mean in 1994. ${ }^{34}$ The levels and the trends of the ratio in the two groups of countries are remarkably similar in the pre-Bosman period and only start to diverge after the Bosman ruling. ${ }^{35}$

\section{[FIGURE 6 ABOUT HERE]}

More formally, the difference-in-differences model assumes that the change in the ratio of female to male enrollment in those countries that are less exposed to the Bosman ruling is an unbiased estimate of the counterfactual. While we cannot directly test this assumption, we can test whether time trends in the two groups of countries were the same in the pre-Bosman period in our full sample. If time trends are the same in the pre-Bosman period, then it is likely that they would have been the same in the post-Bosman period in the absence of the Bosman ruling. To test the hypothesis that the pre-Bosman time trends are not different in the two groups, we estimate a model like the one in (1) using pre-Bosman data (1970 to 1995) for all the countries in the sample, but we replace the Bosman interaction with a linear trend and an interaction term between the linear trend and an exposure dummy (equal to one for the 10 most exposed countries according to Average players). Column (1) in Table 2 shows that the interaction term is not significant, thus validating our difference-in-differences identification strategy.

\section{[TABLE 2 ABOUT HERE]}

As further evidence, in column (2) of Table 2 we include instead separate year dummies for the exposed countries, and all dummy variables capturing the inter- 
action between the year effects and the dummy for the exposed countries turn out non-significant.

Table 3 reports Ordinary Least Squares (OLS) estimates of equation (1). The coefficient associated to the interaction variable between Bosman and Average players is positive and statistically significant in our baseline regression in column (1). An increase of one standard deviation in the number of players in Big Five soccer leagues (normalized by population) is associated with an increase of 1.5 women for every 100 men enrolled in college (evaluated at the sample mean). ${ }^{36}$ Assuming that all the change in the gender parity index comes from a reduction in male enrollment, back-of-the-envelope calculations suggest it requires that 1 out of 7 potential college enrollees from the under-18 subpopulation actively involved in soccer playing (which represents only $14 \%$ of males in the relevant age group) decide not to attend college to generate the estimated effects in Table 3 (evaluated at the sample mean of the ratio of female to male enrollment). ${ }^{37}$

\section{[TABLE 3 ABOUT HERE]}

Our measure of exposure to the Bosman ruling (a country's ratio of players to population) may be inaccurate for players from the countries that host the Big Five leagues. For these players, the Bosman ruling implied not only a jump in soccer salaries, but also a likely decrease in their perceived chances of making it to their domestic leagues (given the increased competition from foreign players). As a robustness check, we have thus run our regression excluding Germany, Italy, Spain, United Kingdom, and France from the sample. As reported in column (2) of Table 3 , the effect of interest is still positive and statistically significant when we exclude the countries hosting the Big Five leagues from the sample.

According to our measure of exposure, the countries most affected by the Bosman ruling are all from Africa, Latin America and the Caribbean, and Europe. ${ }^{38}$ As we show in columns (3) and (4) of Table 3, results are robust to limiting the sample to countries in these three regions, whether or not the Big Five leagues host countries 
are included. Restricting the sample in this way also makes control countries more comparable to exposed countries than in the full sample. The estimated coefficients in columns (3) and (4) are remarkably similar to those in columns (1) and (2), implying an increase of between 1.48 and 1.65 females for every 100 males in college education after a one-standard-deviation increase in Average players (evaluated at the sample mean of the ratio of female to male enrollment).

The specification in logs in equation (1) may be misleading when the ratio of female to male tertiary enrollment takes values close to zero. In our sample, most of the countries having a ratio of female to male tertiary enrollment close to zero are not exposed to the Bosman ruling. For these countries small absolute improvements in the ratio imply percentage variations that cannot be matched by those countries with higher ratios (for example, there are countries that start off with a ratio of 2 and move to a ratio of 10 , a percentage change that cannot be matched by a country that starts off with a ratio of 100). Therefore, as a robustness check we re-run equation (1) with the levels of the ratio of female to male tertiary enrollment on the left-hand side, rather than the logarithm of that ratio. As Table 4 shows, the coefficient of interest remains positive and significant in this specification, even if we exclude Germany, Italy, Spain, United Kingdom, and France, and/or restrict the sample to Africa, Latin America and the Caribbean, and Europe. ${ }^{39}$

\section{[TABLE 4 ABOUT HERE]}

We saw that some regions place a larger number of soccer players in Big Five leagues than others; indeed, the countries most affected by the Bosman ruling are all from Africa, Latin America and the Caribbean, and Europe. This raises the concern that the college gender gap may have evolved differentially over time across regions and that our explanatory variable may in part be capturing such differential trends. To address this concern we allow the ratio of female to male enrollment to grow at a different average annual rate in each region in the regressions reported in Table 5. The estimated coefficients on the interaction variable between Bosman 
and Average players are positive and statistically significant, and somewhat larger than the estimated coefficients in Table 3, implying an increase of around 2.5 women for every 100 men enrolled in college after a one standard-deviation increase in the number of players in Average players.

\section{[TABLE 5 ABOUT HERE]}

To aid in the interpretation of the effect of an increase in the returns to male superstars on the ratio of female to male enrollment, we have generated a discrete measure of exposure to the Bosman ruling, Top countries, an indicator variable that takes the value of one for the top 10 countries according to the ratio of the number of soccer players playing in Big Five leagues to the country's population (in 1994). As reported in columns (1) to (4) of Table 6 the coefficient on the interaction effect between Bosman and Top countries is positive and statistically significant in all the specifications, i.e., whether or not the hosts of the Big Five leagues are included, and whether or not we restrict the sample to countries from Africa, Latin America and the Caribbean, and Europe. Being in the group of countries that are more exposed to the Bosman ruling is associated with an increase in the ratio of female to male tertiary enrollment in the range of 7 to 7.6 women for every 100 men relative to the rest of the countries in the sample. ${ }^{40}$

\section{[TABLE 6 ABOUT HERE]}

Figures 3 and 4 suggest a steady increase in salaries and foreign players in Big Five soccer leagues over the last two decades - the discrete jump around the Bosman ruling notwithstanding. To check that the empirical evidence reported so far is not partly picking up those trends, we have produced estimates of the main equation of interest for the sample of countries with no players in the Big Five leagues in 1994 (roughly half of the countries in the sample, according to Table B1 in Appendix B). As column (1) of Table 7 shows, there is no effect of the Bosman ruling on countries which had no players in the major European leagues. Column (2), in turn, displays the results of re-running equation (1) for the subsample of countries with positive 
values of Average players, and shows a statistically significant effect of roughly the same magnitude as those reported in Table 3.

\section{[TABLE 7 ABOUT HERE]}

Our explanation for the evolution of the college gender gap is predicated on the idea that changes in the labor market returns in soccer affect men's opportunity cost of schooling without altering women's college going decisions. Although we strongly favor the use of the ratio of female to male enrollment as our dependent variable to achieve identification of the effect of interest (as previously discussed), we nevertheless show in Table 8 that the observed increase in the female to male ratio in college attendance is exclusively driven by a reduction in men's attendance.

\section{[TABLE 8 ABOUT HERE]}

We estimate models similar to equation (1), but using the natural logarithms of male and female enrollments as the dependent variable. ${ }^{41}$ Columns (1) to (4) in Table 8 show a negative and mostly significant effect of the Bosman ruling on male enrollment, whereas no effect shows up in columns (5) to (8) for female enrollment - in line with the explanation advanced in this paper. ${ }^{42}$

\section{Concluding remarks}

In this paper we have provided a complementary explanation for the evolution of the college gender gap that puts the focus on the increase in men's opportunity cost of attending college due to an increase in the return of becoming a superstar. We have presented evidence from a natural experiment in European soccer markets (the so-called "Bosman ruling") that generated an exogenous increase in men's (and, crucially, not in women's) payoffs in a prominent superstar path. In line with our explanation, we have found that countries more exposed to the Bosman ruling experienced a significant increase in the ratio of female to male tertiary enrollment in college education relative to less-exposed countries. 
If a college gap favoring females is a cause for concern, it is only natural to guess that institutions may appear to deal with the causes. Athletic scholarships in US universities might be a case in point. By reducing the cost of failing to achieve superstardom in the sport of choice, such an institution could attenuate the effect highlighted in this paper. But as long as boys continue to neglect their studies in favor of sports to try to obtain a scholarship, instead of a direct success in the superstar path, the mechanism we have discussed could still be at work at a lower educational level, such as high school (which should eventually have an effect on the college gender gap). Furthermore, is it conceivable that the mere existence of the athletic scholarships strengthens individual incentives to enter and remain in the superstar path, which could exacerbate the problem. ${ }^{43}$

Even though our natural experiment looked at one particular professional sport, soccer, we expect the mechanics outlined in this paper to be at work in other markets where superstars are present, and in which the gender gap has been increasing in favor of men. For instance, changes in the return to becoming an entrepreneur might also contribute to the college gender gap, given that men are much more likely to become entrepreneurs than women. ${ }^{44}$ An empirical investigation into these ideas must, however, await future research.

\section{Appendix A: A simple model of career choices, hu- man capital accumulation, and lifetime earnings}

\section{A.1 The economic setup}

Consider a population of individuals with two different innate skills. The first skill is a general skill that we call talent, $\theta$, while the other skill is a specific skill that we will denote $\beta$. The two skills are ex-ante unknown to individuals, but it is common knowledge that talent is a random draw from a cumulative distribution function 
$G(\theta ; \lambda)$ defined over $\Theta \subseteq \mathbb{R}$, with parameter $\lambda$ (possibly a vector) and probability density function $g(\theta ; \lambda)>0$ for all $\theta \in \Theta$; and that the specific skill $\beta$ follows a binomial distribution with parameter $p>0$.

At each calendar time $t=0, \ldots, T$, each individual has to decide between two alternative (and mutually exclusive) uses for her skills - we refer to these uses as "career paths": a "regular" path, $R$, and a "superstar" path, S. Each path leads to a different stream of lifetime earnings after time $T$. There is no discounting and there is no cost to individuals from changing from the $S$ path to the $R$ path, but once made, such a choice is irreversible.

Individuals are expected utility maximizers with utility function $u(\cdot)$. To simplify the exposition, we assume $u(\cdot)$ is the identity function. Thus, individuals are risk neutral and maximize expected earnings. ${ }^{45}$ Expected lifetime earnings of individual $i$ in the $R$ path, $w_{i}^{R}$, are increasing in the individual's effective talent, $\eta_{i}$ (i.e., $w_{i}^{R}=w\left(\eta_{i}\right)$, with $w^{\prime}>0$ ). For simplicity, we take $w(\cdot)$ to be linear in $\eta_{i}$ :

$$
w_{i}^{R}=w\left(\eta_{i}\right)=a+b \eta_{i}
$$

where $a, b>0$ are known constants, and $b$ measures the sensitivity of earnings to effective talent.

Effective talent is a function of the individual's innate talent and her human capital accumulated up to T. Human capital can only be accumulated by spending time in the $R$ path. ${ }^{46}$ Letting $\tau_{i}$ denote the time at which individual $i$ chose path $R, T-\tau_{i}$ measures the number of periods of human capital accumulation up to time $T$ (i.e., total time spent on path $R$ ). Individual $i$ 's effective talent at time $T$ is then given by $\eta_{i}=\theta_{i} x_{i T}$, where $x_{i T}=\left(1+T-\tau_{i}\right) .{ }^{47}$ For instance, if the individual chose $R$ at time $T$, then $\tau_{i}=T$ (no human capital accumulation), $x_{i T}=1$ and $\eta_{i}=\theta_{i}$ (effective and innate talent coincide).

In the other career path, $S$, only raw ability (i.e., innate skills $\theta$ and $\beta$ ), is 
important for expected lifetime earnings, $w_{i}^{S} \cdot{ }^{48}$ In particular we assume that both skills are perfect complements in generating $w_{i}^{S}$ :

$$
w_{i}^{S}=\theta_{i} W \Longleftrightarrow \beta_{i}=1
$$

where $W$ is a fixed prize. In case $\beta_{i}=0$, the individual is forced to exit the $S$ path at $t=T$ once it becomes known that she does not have the specific skill $\beta .{ }^{49}$ For these individuals $\tau_{i}=T$ and expected earnings are $\left.w_{i}^{R}\right|_{\tau_{i}=T}=w\left(\theta_{i}\right)$.

A crucial difference between both types of skills is that learning of the realization of $\theta$ predates that of $\beta$ : while $\theta$ becomes known at $t=1$, individuals only learn $\beta$ at $t=T>1$, provided they stayed in path $S$ until $T$. As an example, consider an individual with a natural talent for basketball. Such a characteristic $(\theta)$ is usually known at a young age. Whether the individual will have the necessary height to play professional basketball, however, can only be known later, say after adolescence. In the same vein, an individual can be talented for tennis, but never make it to the professional circuit because she discovers that she cannot handle pressure or stay away from home for a very long time. A somewhat different example is a young wannabe entrepreneur, who is selected by an angel investor (like the Thiel Foundation) to receive funds to develop her idea, but eventually discovers she is not the next Bill Gates or Steve Jobs, and fails in the endeavor. ${ }^{50}$

For simplicity, let $T=2$ in what follows. ${ }^{51}$ Summing up:

1. At $t=0$, individuals decide which path, $R$ or $S$, to follow, without knowledge of their skills, $\theta_{i}$ and $\beta_{i}$. Given that at this stage all individuals have the same information and beliefs, they all make the same decision. We focus on the most interesting case in which all individuals choose the superstar path $S$ at this time.

2. At $t=1$, individuals learn their innate talent $\theta$, but they are still uncertain about their specific skill $\beta$. Each individual then decides whether to exit or 
not from the $S$ path. The decision to exit is irreversible. Individuals choosing path $R$ accumulate human capital in this period.

3. At $t=2$, individuals who decided to stay in the $S$ path in the previous period learn their specific skill $\beta$. With probability $p$, an individual observes $\beta_{i}=1$, and with probability $1-p$, she observes $\beta_{i}=0$ and is forced to exit to the regular path $R$. Payoffs accrue according to (A1) and (A2).

\section{A.2 Equilibrium analysis and predictions}

At $t=2$, expected lifetime earnings of individuals who chose path $R$ at $t=1$ are given by:

$$
\left.w_{i}^{R}\right|_{\tau_{i}=1}=a+\left.b \eta_{i}\right|_{\tau_{i}=1}=a+2 b \theta_{i}
$$

Among individuals that did not exit path $S$ at $t=1$, some learn that $\beta_{i}=1$ at $t=2$ and earn:

$$
w_{i}^{S}=\theta_{i} W
$$

but those who learn that their $\beta_{i}=0$ have expected lifetime earnings given by:

$$
\left.w_{i}^{R}\right|_{\tau_{i}=2}=a+\left.b \eta_{i}\right|_{\tau_{i}=2}=a+b \theta_{i}
$$

At $t=1$, an individual will decide to exit the $S$ path if expected lifetime earnings are greater in the regular path $R$; i.e., individual $i$ chooses path $R$ if and only if:

$$
a+2 b \theta_{i}>p W \theta_{i}+(1-p)\left(a+b \theta_{i}\right)
$$

or, put differently, if her talent (known at this time) is low enough:

$$
\theta_{i}<\theta^{*} \equiv \frac{p a}{p W-(1+p) b}
$$


Provided that $p W>(1+p) b$, there exists an individual with $\theta_{i}=\theta^{*}$ who is just indifferent between career paths after learning her $\theta_{i} \cdot{ }^{52}$ For all individuals with $\theta_{i}<\theta^{*}$, we have $\tau_{i}=1$. Hence, the proportion of individuals in the population that exit the $S$ path at $t=1$ and start investing in their human capital is given by $G\left(\theta^{*} ; \lambda\right)$. Intuitively, less gifted individuals compensate their lower innate talent with human capital accumulation, so that their effective talent ends up being larger than for more gifted individuals (i.e., individuals born with a higher $\theta$ ), but who decided to stay longer in the $S$ path. ${ }^{53}$ Notice that $G\left(\theta^{*} ; \lambda\right)$ is decreasing in $W$ since $\partial \theta^{*} / \partial W<0$ and $g(\theta ; \lambda)>0$ for all $\theta .{ }^{54}$

Suppose there are two groups $(M, F)$ of individuals in the population characterized as before, and that only differ in the $W$ they face. Given the expected earnings of each group in the superstar path it is straightforward to compute the fraction of individuals in each group with higher capital accumulation, $G\left(\theta_{M}^{*}\left(W^{M}\right) ; \lambda\right)$ and $G\left(\theta_{F}^{*}\left(W^{F}\right) ; \lambda\right)$, where we have made explicit the dependence of $\theta^{*}$ on the $W$ faced by each group. We interpret $\lambda$ as capturing other determinants of human capital investments that affect both groups of individuals.

Suppose now that there is a shock $\sigma$ that increases $W^{M}$ but (crucially) not $W^{F}$, and which may also affect $\lambda$ (in any direction). Such a shock has a direct negative effect on the human capital accumulation of group $M$ (because $\partial G(\theta ; \lambda) / \partial \theta>0$ and $\partial \theta^{*} / \partial W<0$ from equation $\left.(\mathrm{A} 3)\right)$, but its total effect is uncertain because of the confounding effect of other determinants of human capital decisions that might be affected by the shock (i.e., when $\partial \lambda / \partial \sigma \neq 0) .{ }^{55}$ However, if $G(\cdot)$ is multiplicatively separable in $\theta$ and $\lambda$, we can obtain an unambiguous prediction for the effect of the shock to $W^{M}$ on the human capital accumulation ratio of group $F$ to group $M .^{56}$ Letting $\Omega$ denote this ratio and assuming $G(\theta ; \lambda)=\lambda H(\theta), H^{\prime}>0$ for all $\theta \in \Theta$, 
we have: ${ }^{57}$

$$
\begin{aligned}
\Omega & =\frac{\lambda(\sigma) H\left(\theta_{F}^{*}\left(W^{F}\right)\right)}{\lambda(\sigma) H\left(\theta_{M}^{*}\left(W^{M}(\sigma)\right)\right)} \\
& =\frac{H\left(\theta_{F}^{*}\left(W^{F}\right)\right)}{H\left(\theta_{M}^{*}\left(W^{M}(\sigma)\right)\right)} .
\end{aligned}
$$

A simple comparative-statics exercise with respect to $\sigma$ on $\Omega$ yields our main result:

Proposition 1 Suppose there are two groups $(M, F)$ of individuals in the population that differ only in the $W$ they face. Then, a positive shock $\sigma$ to the prize that group $M$ faces in the superstar path, $W^{M}$, will increase the ratio of human capital accumulation $\Omega ;$ i.e., $d \Omega / d \sigma>0$.

Proof. Totally differentiating equation (A4) with respect to $\sigma$ yields

$$
\frac{d \Omega}{d \sigma}=\frac{\frac{\partial H\left(\theta_{F}^{*}\left(W^{F}\right)\right)}{\partial \sigma} H\left(\theta_{M}^{*}\left(W^{M}(\sigma)\right)\right)-\frac{\partial H\left(\theta_{M}^{*}\left(W^{M}(\sigma)\right)\right)}{\partial \sigma} H\left(\theta_{F}^{*}\left(W^{F}\right)\right)}{H\left(\theta_{M}^{*}\left(W^{M}(\sigma)\right)\right)^{2}}
$$

Since $\sigma$ does not affect the prize faced by individuals in group $F, H\left(\theta_{F}^{*}\left(W^{F}\right)\right)$ remains unchanged: $\partial H\left(\theta_{F}^{*}\left(W^{F}\right)\right) / \partial \sigma=0$. Therefore,

$$
\operatorname{sgn}\left(\frac{d \Omega}{d \sigma}\right)=-\operatorname{sgn}\left(\frac{\partial H\left(\theta_{M}^{*}\left(W^{M}(\sigma)\right)\right)}{\partial \sigma}\right)
$$

Given that $\partial H\left(\theta_{M}^{*}\left(W^{M}(\sigma)\right)\right) / \partial \sigma=\left[\partial H\left(\theta_{M}^{*}\left(W^{M}(\sigma)\right)\right) / \partial \theta\right]$ $*\left[\partial \theta_{M}^{*}\left(W^{M}(\sigma)\right) / \partial W^{M}\right] *\left[\partial W^{M}(\sigma) / \partial \sigma\right], \partial W^{M}(\sigma) / \partial \sigma>0$ by definition, $\partial \theta_{M}^{*}\left(W^{M}(\sigma)\right) / \partial W^{M}<0$ from equation (A3), and $\partial H\left(\theta_{M}^{*}\left(W^{M}(\sigma)\right)\right) / \partial \theta>0$, we can conclude that $\partial H\left(\theta_{M}^{*}\left(W^{M}(\sigma)\right)\right) / \partial \sigma<0$, and hence $d \Omega / d \sigma>0$.

Proposition 1 provides a potential explanation for the puzzle about why women are catching up to men, and have in many countries overtaken them, in terms of college enrollment and completion. Under the premise that payoffs in the superstar 
path (e.g., professional sports) increase for men, but not for women, our model predicts that men are more likely to stay longer in the superstar path to the detriment of their accumulation of human capital (say, by engaging sports rather than enrolling in college). Thus, we should observe that an increase in $W^{M}$ leads to an increase in the ratio of female to male enrollment in college - a claim we have supported with causal evidence in Section 3.

\section{Appendix B: Countries' exposure to the Bosman}

\section{ruling}

[TABLE B1 HERE]

\section{Notes}

${ }^{1}$ See Vincent-Lancrin (2008) for a recent summary of common explanations.

${ }^{2}$ According to this explanation, the college gender gap should be more pronounced in poorer, less-educated households. Goldin, Katz, and Kuziemko (2006), however, report that there are no significant differences in college completion rates by gender across the socioeconomic status distribution (at least in the United States).

${ }^{3}$ Participation in sports could also increase general human capital, as broadly shown in existing research (Barron, Ewing and Waddell, 2000; Eide and Ronan, 2001; Lipscomb, 2007; Pfeifer and Cornelißen, 2010; Rees and Sabia, 2010; Stevenson, 2010). As long as this accumulation occurs at a lower rate than in traditional education/training, the mechanism we emphasize would still be at work. We address this issue again in Appendix A.

${ }^{4}$ Concern about the educational choices of men seem to be of more than just academic interest. Educators and college admissions officials in the United States have 
been recently voicing their concerns about the dwindling presence of men in colleges, and some are even speculating that some sort of affirmative action might be needed in the near future to deal with gender imbalances. For a sample of views on the subject, check, for instance, http://usatoday30.usatoday.com/news/education/200510-19-male-college-cover_x.htm, http://www.collegepossible.org/, and http://www. postsecondary.org/. On admission criteria that favor men, check further Long (2007) and Bailey and Smith-Morest (2006).

${ }^{5}$ See http://sports.espn.go.com/espn/news/story?id=6391145 for the top paid athlete by country (accessed March 2014). The only three women that appear among the world top 100 are tennis players, the sport generally considered to be the one with the smallest gender pay gap among professional sports. Only one woman made it to the top 50: Maria Sharapova, ranked 22nd (source: http://www.forbes.com/ sites/kurtbadenhausen/2013/06/05/the-worlds-highest-paid-athletes-2013-behind-thenumbers/, accessed March 2014).

${ }^{6}$ Another factor that can explain why the superstar path is more appealing for men is that men are more competitive than women. For robust experimental evidence on the subject, see Gneezy, Niederle, and Rustichini (2003), and Niederle and Vesterlund (2007). Buser, Niederle, and Oosterbeek (forthcoming) link gender differences in competitiveness to career choices.

${ }^{7}$ See http://www.topendsports.com/world/lists/earnings/forbes-index.htm (accessed March 2014).

${ }^{8}$ Our work is broadly related to the literature studying the impact of labor market conditions on schooling decisions, as in, for instance, Eckstein and Wolpin (1995) and Flabbi and Tejada (2012).

${ }^{9}$ Charles and Luoh (2003) argue that greater uncertainty on returns for men would make risk-averse men study less and present data consistent with a larger increase in uncertainty for men relative to women over time; similar to our paper, the authors put the focus on men when explaining the college gender gap. 
${ }^{10}$ In Appendix A we develop a simple model of career choices in which an increase in the return of becoming a superstar increases the opportunity cost of pursuing college studies and generates the observed phenomenon as a result.

${ }^{11}$ Many rankings of popular sports can be devised, each ranking using different criteria (viewership, players, revenue) and sources (facts, personal opinion, online votes). Soccer (association football) appears on top in every credible ranking that can be found on the Internet (see, e.g., http://www.topendsports.com/world/lists/ popular-sport/analysis.htm). The FIFA World Cup's final game is the single most viewed sporting event: the 2010 match between Spain and The Netherlands was watched by an estimated 700 million people.

${ }^{12}$ Along with the seven soccer clubs, three American teams - the Yankees, Los Angeles Lakers, and Philadelphia Phillies - are represented in the top 10. No NFL team in the league started 2011 with a payroll higher than 75th (Pittsburgh Steelers, who payed an average of $\$ 2.9$ million per player). See http://espn.go.com/espn/story/_/ id/7850531/espn-magazine-sportingintelligence-global-salary-survey-espn-magazine for the full story.

${ }^{13}$ See Deloitte's Annual Review of Football Finance at http://www.deloitte.com/view/ en_GB/uk/industries/sportsbusinessgroup/sports/football/annual-review-of-footballfinance/.

${ }^{14}$ Figures for the US are from the Major League Soccer Players Union and can be checked at http://www.mlsplayers.org/salary_info.html. Minimum wages for South American players were obtained from http://www.elsalario.com.ar/main/trabajodecente/Informeslaborales/argentina-tiene-el-salario-minimo-mas-alto-de and http:// www.agremiados.com.ar/faa/notas/2010/04/09/61700.html.

${ }^{15}$ See http://www.forbes.com/sites/christinasettimi/2013/04/17/the-worlds-bestpaid-soccer-players/.

${ }^{16}$ In constant US dollars, Maradona's annual salary is less than $3 / 4$ of what the average FC Barcelona's player earns per week. For English salaries, see http:// 
www.sportingintelligence.com/2011/01/20/from-20-to-33868-per-week-a-quick-historyof-english-footballs-top-flight-wages-200101/.

${ }^{17}$ The figures are from the website of Transfermarkt GmbH \& Co. KG (http:// www.transfermarkt.com/).

${ }^{18}$ See http://content.time.com/time/world/article/0,8599,2049502,00.html.

${ }^{19}$ UEFA is the governing body of European Soccer. The rule was colloquially referred to as the " $3+2$ " rule, because it permitted each national association to limit to three the number of foreign players whom a club may field in any first division match in their national championships, plus two players who had played in the country of the relevant national association for an uninterrupted period of five years, including three years as a junior (http://eur-lex.europa.eu/smartapi/cgi/sga_doc?smartapi! celexplus!prod!CELEXnumdoc\&lg=en\&numdoc=61993J0415).

${ }^{20}$ Such a rule was similar to the reserve clause once common in North American professional sports.

${ }^{21}$ Article 39 (formerly 48) states: "1. Freedom of movement for workers shall be secured within the Community. 2. Such freedom of movement shall entail the abolition of any discrimination based on nationality between workers of the Member States as regards employment, remuneration and other conditions of work and employment. 3. It shall entail the right, subject to limitations justified on grounds of public policy, public security or public health: (a) to accept offers of employment actually made; (b) to move freely within the territory of Member States for this purpose; (c) to stay in a Member State for the purpose of employment in accordance with the provisions governing the employment of nationals of that State laid down by law, regulation or administrative action; (d) to remain in the territory of a Member State after having been employed in that State, subject to conditions which shall be embodied in implementing regulations to be drawn up by the Commission. 4. The provisions of this article shall not apply to employment in the public service" (http://eur-lex.europa.eu/LexUriServ/LexUriServ.do?uri=CELEX:12002E039:EN:HTML). 
The full judgment can be found at http://eur-lex.europa.eu/smartapi/cgi/sga_doc? smartapi!celexplus!prod!CELEXnumdoc\&lg $=$ en\&numdoc $=61993 J 0415$.

${ }^{22}$ See, for example, Frick and Simmons' chapter in the Handbook on the Economics of Professional Football (Frick and Simmons, 2014), and media reports in http://content.time.com/time/world/article/0,8599,2049502,00.html and http://news.bbc.co.uk/ sport2/hi/football/4528732.stm. The impact of free agency on salaries comes as no surprise when comparing with previous experiences with free agency in US professional sports, beginning with baseball in 1976. For a general overview, see Kahn (2000). Player mobility between clubs also increased dramatically in the US with free agency; see, e.g., Goldberg (2008).

${ }^{23}$ See http://footballspeak.com/post/2012/05/05/Top-20-Highest-Paid-Players.aspx.

${ }^{24}$ Information on player salaries is seldom made available by European clubs, and systematic data from before the Bosman ruling are especially difficult to find. There is no European equivalent to USA Today Sports Salary Database or Rodney Fort's Sports Business Data, which compile consistent salary information for players in North American major leagues. The only comprehensive publicly available source of soccer salaries comes from Corriere dello Sport, but is limited to Italy's Serie A and only begins in 2009 (Frick and Simmons, 2014).

${ }^{25}$ Fraud can also be a source of EU passports: the fake passport scandal that began in the Italian Serie A in 2000, when as many as nine South American players were implicated in suspicions over the provision of false Italian and Portuguese passports to enable their clubs to field them as Europeans, illustrates the importance to non-EU players of obtaining a EU passport. Shortly after, other three South American players were found guilty of using fake European passports and banned from entering France. At an informal meeting in 2001, officials from France, Spain, Italy, Portugal, and the UK discussed the role of criminal organizations in the supply of the fake documents. For the full stories, see http://news.bbc.co.uk/sport2/hi/football/europe/962023.stm, http://sportsillustrated.cnn.com/ 
soccer/news/2001/03/23/fake_passports_ap/, and http://news.bbc.co.uk/sport2/hi/ football/europe/1260498.stm.

${ }^{26}$ Tertiary education includes categories 5 and 6 of the 1997 International Standard Classification of Education (ISCED), a statistical framework for organizing information on education maintained by the United Nations Educational, Scientific and Cultural Organization (UNESCO), and refers basically to undegraduate and graduate studies leading to a degree. See http://www.uis.unesco.org/Education/ Pages/international-standard-classification-of-education.aspx for details.

${ }^{27}$ The data are accesible at http://databank.worldbank.org/data/views/variable Selection/selectvariables.aspx?source=world-development-indicators. The series used is Ratio of female to male tertiary enrollment. The series was downloaded on $02 / 06 / 2014$.

${ }^{28}$ The 7 countries are Afghanistan, Djibouti, Grenada, Guyana, Madagascar, Qatar, and St. Kitts and Nevis. As an example of implausible data, St. Kitts and Nevis reported a ratio of female to male enrollment of 267 in 1985, and then just 73 in 1986, while Djibouti had a ratio of only 44 in 1992 and jumped to 128 in 1993. All of our results are robust to the inclusion of these countries.

${ }^{29}$ Prior to the ECJ judgment, players with a German, Italian, Spanish, UK, or French passport could play for a team in the corresponding Big Five league without occupying a non-national slot. After the judgment, they could play for any team in a Big Five league as a national.

${ }^{30}$ The total number of players in the 1994/95 season in Big Five leagues by country was obtained from the website of Transfermarkt GmbH \& Co. KG (http:// www.transfermarkt.com/; accessed on 04/14/2014).

${ }^{31}$ For instance, Sergio Agüero was born in Argentina to Argentine parents, developed as soccer player in Argentina, plays for Argentina's national team, and holds both Argentine and Spanish passports. Thanks to his Spanish passport he did not occupy a non-EU slot at his former team, Atlético de Madrid, but is nev- 
ertheless counted as a foreign player in the Spanish Liga for our purposes. Players from Northern Ireland, Wales and Scotland have been considered nationals to the English Premier League, as they are all citizens of the United Kingdom.

${ }^{32}$ Population data were obtained from the World Bank's World Development Indicators (series name: Population (Total), downloaded on 02/06/2014). Our measure is likely to grossly underestimate the chances men actually perceive. A more accurate estimate would obtain from dividing a country's number of players in Big Five leagues by the country's number of professional players or under-18 players. Using data from the FIFA Big Count of 2006, this alternative calculation would increase our measure of perceived chances by a factor of between 500 and 55,000, depending on the denominator used. Unfortunately, no pre-Bosman data exists for professional and under-18 players by country. Another, more subtle, reason why our measure could be underestimating the perceived chances of making it to a Big Five league is overconfidence or overoptimism; see Lee (1983) for early evidence of such a behavior among male high school athletes in the United States, and http://www.lanacion.com.ar/1759390-los-que-necesitan-regresar-pararecuperar-el-impulso on the increased expectations of young Argentine soccer players.

${ }^{33}$ To improve comparability between exposed and unexposed countries, we restrict most of the analyses below to country-year observations with ratios of female to male tertiary enrollment above 40 . This means dropping around $10 \%$ of our observations, the vast majority of them from unexposed countries. Besides, our specification in logs cannot deal with zeros and may be misleading when the ratio of female to male tertiary enrollment takes values close to zero - see below.

${ }^{34}$ The exposed group consists of the top 10 countries according to the ratio of the number of soccer players playing in Big Five leagues to the country's population (in 1994).

${ }^{35}$ Given that our data panel is unbalanced, the figure should be interpreted with 
caution, as composition effects might be at work. However, our formal results below show that the simple message the figure sends holds when appropriately dealing with those effects.

${ }^{36}$ Since the gender parity index is the ratio of the proportion of females enrolled in college in the five-year age group following on from secondary school leaving to the same proportion for males, variations in this index cannot be strictly interpreted as a number of women for every 100 men. However, for ease of interpretation and intuitive appeal, we will be using the "women for every 100 men" concept as a rough interpretation of the results. Moreover, the interpretation is exact when the numbers of males and females in that age group are equal (as seem to be the case at least for OECD countries, for which the appropriate age groups by gender are available).

${ }^{37}$ We have estimated the number of males attending college from the World Development Indicators series (School enrollment, tertiary, male, downloaded on 02/06/2014) using the fraction of population aged 20-24 in OECD countries (http:// stats.oecd.org/Index.aspx?DataSetCode=RPOP\#; accessed on 04/11/2014). The figures for players under 18 come from the 2006 FIFA Big Count. We have assumed that $1 / 10$ of them are about 17 years old and facing a college decision shortly after. OECD data was also used to proxy for the number of males aged 17 in the population.

${ }^{38}$ The first country outside these regions to appear is New Zealand, ranked 22nd.

${ }^{39}$ All the results are also robust to lifting the restriction on observations with a female-male enrollment ratio below 40.

${ }^{40} \mathrm{All}$ of these results are robust to the inclusion of regional trends (not reported).

${ }^{41}$ The series used are School enrollment, tertiary, male and School enrollment, tertiary, female. The data are accesible at http://databank.worldbank.org/data/views/ variableSelection/selectvariables.aspx?source=world-development-indicators. The series were downloaded on 02/06/2014. 
${ }^{42}$ Incidentally, we note that the effect on male enrollment is of the same sign and order of magnitude of that implied by our back-of-the-envelope calculations in our discussion of Table 3 .

${ }^{43}$ Besides, it is unclear how it would be possible to target scholarships to boys without violating Title IX, a law passed in United States in 1972 that requires equal funding for male and female athletes, including scholarship distribution.

${ }^{44}$ See http://www.oecd.org/publications/factbook/oecdfactbook2011-2012.htm and http://www.bls.gov/opub/mlr/2010/09/art2full.pdf (accessed April 2014).

${ }^{45}$ Risk neutrality is not central to our results. All of them continue to hold with a general utility function as long as $u^{\prime}>0$, a mild condition. Proofs are available upon request.

${ }^{46}$ All our predictions are robust to the possibility that individuals also accumulate human capital in the $S$ path, as long as this accumulation occurs at a lower rate than in $R$. Proofs are available upon request.

${ }^{47}$ This formulation is akin to that of Gibbons and Waldman (1999), who use $\eta_{i}=\theta_{i} h\left(x_{i T}\right)$, where $h^{\prime}>0$ and $h^{\prime \prime} \leq 0$. We adopt a linear specification for $h$ for simplicity.

${ }^{48}$ There are plenty of reasons to believe that skills are indeed multidimensional and that the human traits determining success as a, say, soccer player are very different from those predicting success in more standard professions. In the model, these differences are "black-boxed" into the dichotomous parameter $\beta$. The qualitative predictions of the model still obtain if we include an equivalent parameter for the regular path (for instance, individuals may discover their specific skills to become, say, lawyers only once they enter college). Proofs are available upon request.

${ }^{49}$ Alternatively, $w_{i}^{S}=0$ if $\beta_{i}=0$, and the individual is allowed to choose which path to take after $t=T$. Given our assumptions, individual $i$ would always choose path $R$ under those circumstances, and earn $w_{i}^{R}=w\left(\theta_{i}\right)$.

${ }^{50}$ Since 2010, The Thiel Foundation selects 20-25 students under the age of 
20 per year through a competitive process to receive a fellowship of $\$ 100,000$ over two years if they drop out of school to pursue scientific research or create a startup. Doubts about the success of the initiative are multiplying. See, e.g., http://www.forbes.com/sites/singularity/2013/09/11/peter-thiel-promised-flying-carsinstead-we-got-caffeine-spray/.

${ }^{51}$ Allowing for $T>2$ is straightforward in our setup, and it would amount to letting individuals accumulate human capital for a longer period of time. Such an assumption would mechanically operate against our main result, and hence $T=2$ can be seen as the most conservative assumption.

${ }^{52}$ In general, the assumption needed is that expected utility be more responsive to innate talent in the superstar path than in the regular path. See Gibbons and Waldman (1999) for similar assumptions.

${ }^{53}$ By the Law of Large Numbers, a fraction $1-p$ of individuals who exit at $t=1$ also have $\beta=0$. These individuals are strictly of lower talent than individuals like who did not exit, even when the specific skill is considered in the definition of "more gifted". In any case, since the specific skill is useless in $R$, the definition of "gifted" just in terms of $\theta$ is also warranted.

${ }^{54}$ This result does not hinge on the linearity assumption, but just on having $W$ large enough. The proof is available from the authors upon request. In the Bosman case analyzed in the main text, $p$ could also be increasing simultaneously with $W$. It is clear from (A3) that such a change would reinforce the effect of $W$ on $\theta^{*}$.

${ }^{55}$ For instance, if a shock to the superstar market reduces labor supply in the regular job market, expected salaries would increase in $R$ (for given demand) - which could make the regular path more attractive for women and men (not previously engaged in $R$ or $S$ ), yielding $\partial \lambda / \partial \sigma>0 . \lambda(\sigma)$ attempts to capture this kind of situations in reduced form.

${ }^{56}$ If $\partial \lambda / \partial \sigma$ turns out to be zero, assuming separability would imply no loss of generality since it would yield exactly the same comparative statics. However, if 
$\partial \lambda / \partial \sigma \neq 0$, separability allows for a clear prediction where not assuming it would not.

${ }^{57}$ Given that $G$ and $H$ are cumulative distribution functions, we are implicitly assuming that $\lambda$ is such that for $G, H \in[0,1]$ for every $\theta$.

\section{References}

Abramitzky, Ran, and Victor Lavy, "How Responsive is Investment in Schooling to Changes in Redistribution Policies and in Returns," NBER Working Paper No. w17093, May 2011.

Atkin, David, "Endogenous Skill Acquisition and Export Manufacturing in Mexico," NBER Working Paper No. w18266, August 2012.

Averett, Susan, and Mark L. Burton, "College Attendance and the College Wage Premium: Differences by Gender," Economics of Education Review 15:1 (February 1996), 37-49.

Bailey, Thomas, and Vanessa Smith-Morest (ed.), Defending the Community College Equity Agenda, 1st ed. (Baltimore, MA: Johns Hopkins University Press), 2006.

Barron, John M., Bradley T. Ewing, and Glen R. Waddell, "The Effects of High School Athletic Participation on Education and Labor Market Outcomes," The Review of Economics and Statistics 82:3 (August 2000), 409-421.

Becker, Gary, Human Capital and the Personal Distribution of Income (Ann Arbor, MI: University of Michigan Press), 1967.

Ben-Porath, Yoram, "The Production of Human Capital and the Life Cycle of Earnings," Journal of Political Economy 75:4 (August 1967), 352-365.

Bobba, Matteo, Luca Flabbi, and Santiago Levy, "Labor Market Policies and Schooling Investments," draft prepared for the Workshop Labor Market Opportunities and Schooling Investments, IDB, September 2012. 
Buchmann, Claudia, and Thomas DiPrete, "The Growing Female Advantage in College Completion: The Role of Family Background and Academic Achievement," American Sociological Review 71:4 (August 2006), 515-541.

Buser, Thomas, Muriel Niederle, and Hessel Oosterbeek, "Gender, Competitiveness and Career Choices," The Quarterly Journal of Economics, forthcoming, 2014 (First published online: May 8, 2014).

Charles, Kerwin Kofi, and Ming-Ching Luoh, "Gender Differences in Completed Schooling," The Review of Economics and Statistics 85:3 (August 2003), 559-577.

Chen, Kelly, Nicole Fortin, Philip Oreopoulos, and Shelley Phipps, "School Start Age and Hyperactivity in Canadian Children," unpublished manuscript, Dalhousie University, 2011.

DiPrete, Thomas, and Claudia Buchmann, "Gender-Specific Trends in the Value of Education and the Emerging Gender Gap in College Completion," Demography 43:1 (February 2006), 1-24.

Dobson, Stephen, and John Goddard, The Economics of Football (New York, NY: Cambridge University Press), 2011.

Dougherty, Christopher, "Why Are the Returns to Schooling Higher for Women than for Men?," The Journal of Human Resources 40:4 (Autumn 2005), 969-988.

Downey, Blair, "The Bosman Ruling: European Soccer - Above the Law?," Asper Review of International Business and Trade Law 1 (2001), 187-198.

Eckstein, Zvi, and Kenneth I. Wolpin, "Duration to First Job and the Return to Schooling: Estimates from a Search-Matching Model," Review of Economic Studies 62:2 (April 1995), 263-286.

Eide, Eric R., and Nick Ronan, "Is Participation in High School Athletics an Investment or a Consumption Good? Evidence from High School and Beyond," Economics of Education Review 20:5 (October 2001), 431-442.

Feess, Eberhard, Michael Gerfin, and Gerd Muehlheusser, "The Incentive Effects of Long-Term Contracts on Performance: Evidence from a Natural Experiment 
in European Soccer," unpublished manuscript, Frankfurt School of Finance and Management, University of Bern, and University of Bielefeld, February 2010.

Flabbi, Luca, and Mauricio Tejada, "Gender Gaps in Education and Labor Market Outcomes in the United States: The Impact of Employers' Prejudice," IDB Working Paper No. IDB-WP-357, December 2012. Available at SSRN: http://ssrn.com/ abstract $=2234315$ or http://dx.doi.org/10.2139/ssrn.2234315.

Fortin, Nicole, "Higher Education Policies and the College Premium: CrossState Evidence from the 1990s," The American Economic Review 96:4 (December 2006), 959-987.

Fortin, Nicole, Philip Oreopoulos, and Shelley Phipps, "Leaving Boys Behind: Gender Disparities in High Academic Achievement," NBER Working Paper No. w19331, August 2013.

Frick, Bernd, "The Football Players' Labor Market: Empirical Evidence from the Major European Leagues," Scottish Journal of Political Economy 54:3 (July 2007), 422-446.

Frick, Bernd, and Rob Simmons, "The Footballers' Labor Market After the Bosman Ruling," in John Goddard and Peter Sloane (ed.), Handbook on the Economics of Professional Football (Cheltenham, UK: Edward Elgar Publishing Limited), 2014.

Gibbons, Robert, and Michael Waldman, "A Theory of Wage and Promotion Dynamics Inside Firms," The Quarterly Journal of Economics 114:4 (November 1999), 1321-1358.

Gneezy, Uri, Muriel Niederle, and Aldo Rustichini, "Performance in Competitive Environments: Gender Differences," The Quarterly Journal of Economics 118:3 (August 2003), 1049-1074.

Goldberg, Jonathan, "Player Mobility in Professional Sports: From the Reserve System to Free Agency," Sports Lawyers Journal 15 (2008), 21-57.

Goldin, Claudia, "The Long Road to the Fast Track: Career and Family," The 
Annals of the American Academy of Political and Social Science 596:Mommies and Daddies on the Fast Track: Success of Parents in Demanding Professions (November 2004), 20-35.

Goldin, Claudia, and Lawrence F. Katz, "The Power of the Pill: Oral Contraceptives and Women's Career and Marriage Decisions," Journal of Political Economy 110:4 (August 2002), 730-770.

Goldin, Claudia, Lawrence F. Katz, and Ilyana Kuziemko, "The Homecoming of American College Women: The Reversal of the College Gender Gap," The Journal of Economic Perspectives 20:4 (Fall 2006), 133-156.

Heath, Rachel, and A. Mushfiq Mobarak, "Does Demand or Supply Constrain Investments in Education? Evidence from Garment Sector Jobs in Bangladesh," unpublished manuscript, University of Washington and Yale University, August 2012.

Kahn, Lawrence, "The Sports Business as a Labor Market Laboratory," The Journal of Economic Perspectives 14:3 (Summer 2000), 75-94.

Lee, Courtland C., "An Investigation of the Athletic Career Expectations of High School Student Athletes," The Personnel and Guidance Journal 61:9 (May 1983), 544-547.

Lipscomb, Stephen, "Secondary School Extracurricular Involvement and Academic Achievement: A Fixed Effects Approach," Economics of Education Review 26:4 (August 2007), 463-472.

Long, Bridget T., "The Reversal of the College Gender Gap: the Role of Alternatives and College Supply," unpublished manuscript, Harvard and NBER, 2007.

McDaniel, Anne, "The Gender Gap in Educational Expectations, 1970-2003", unpublished manuscript, Ohio State University, 2007.

Munshi, Kaivan, and Mark Rosenzweig, "Traditional Institutions Meet the Modern World: Caste, Gender, and Schooling Choice in a Globalizing Economy," The American Economic Review 96:4 (December 2006), 1225-1252. 
Niederle, Muriel, and Lise Vesterlund, "Do Women Shy Away from Competition? Do Men Compete Too Much?," The Quarterly Journal of Economics 122:3 (August 2007), 1067-1101.

Ono, Hiroshi, "Are Sons and Daughters Substitutable? Allocation of Family Resources in Contemporary Japan," Journal of the Japanese and International Economies 18:2 (June 2004), 143-160.

Pfeifer, Christian, and Thomas Cornelißen, "The Impact of Participation in Sports on Educational Attainment-New Evidence from Germany," Economics of Education Review 29:1 (February 2010), 94-103.

Poli, Raffaele, “Africans' Status in the European Football Players' Labour Market," Soccer E Society 7:2-3 (2006), 278-291.

Poli, Raffaele, "Understanding Globalization through Football: The New International Division of Labour, Migratory Channels and Transnational Trade Circuits," International Review for the Sociology of Sport 45:4 (November 2010), 491506.

Rees, Daniel I., and Joseph J. Sabia, "Sports Participation and Academic Performance: Evidence from the National Longitudinal Study of Adolescent Health," Economics of Education Review 29:5 (October 2010), 751-759.

Stevenson, Betsey, "Beyond the Classroom: Using Title IX to Measure the Return to High School Sports," The Review of Economics and Statistics 92:2 (May 2010), 284-301.

Tansel, Aysit, "Determinants of School Attainment of Boys and Girls in Turkey: Individual, Household and Community Factors," Economics of Education Review 21:5 (October 2002), 455-470.

Vincent-Lancrin, Stephan, "The Reversal of Gender Inequalities in Higher Education: An Ongoing Trend," in OECD, Higher Education to 2030 (Vol. 1): Demography (Paris: OECD Centre for Educational Research and Innovation), 2008. 
Table 1. Summary statistics

\begin{tabular}{c|cccc}
\hline Variable & Mean & $\begin{array}{c}\text { Standard } \\
\text { deviation }\end{array}$ & Minimum & Maximum \\
\hline Female to male tertiary enrollment & 86.30 & 47.44 & 0 & 530.86 \\
Players in Big Five soccer leagues in 1994 & 2.48 & 4.87 & 0 & 25.09 \\
Average players & 0.39 & 1.05 & 0.00 & 7.52 \\
\hline
\end{tabular}

Notes: Female to male tertiary enrollment corresponds to yearly data from the World Development Indicators for the period 1970 to 2011. Players in Big Five soccer leagues in 1994 is the number of players by country in 1994. Average players is the ratio of Players in Big Five soccer leagues in 1994 to each country's population in 1994. The Big Five leagues are the German Bundesliga, Italian Serie A, Spanish Liga, English Premier League, and French Ligue 1. 
Table 2. Pre-treatment trends

\begin{tabular}{|c|c|}
\hline \multicolumn{2}{|c|}{ Dependent variable: $\mathrm{Ln}$ (Female to male tertiary enrollment) } \\
\hline & (2) \\
\hline Time trend & $\begin{array}{c}0.023 * * * \\
(0.002)\end{array}$ \\
\hline Top countries x Time trend & $\begin{array}{c}0.004 \\
(0.008)\end{array}$ \\
\hline Top countries x 1971 & $\begin{array}{c}-0.0051 \\
(0.1022)\end{array}$ \\
\hline Top countries x 1972 & $\begin{array}{c}0.1133 \\
(0.0891)\end{array}$ \\
\hline Top countries x 1973 & $\begin{array}{c}-0.0112 \\
(0.0444)\end{array}$ \\
\hline Top countries x 1974 & $\begin{array}{l}-0.0097 \\
(0.0507)\end{array}$ \\
\hline Top countries x 1976 & $\begin{array}{c}-0.0092 \\
(0.0861)\end{array}$ \\
\hline Top countries x 1977 & $\begin{array}{c}0.0657 \\
(0.1098)\end{array}$ \\
\hline Top countries x 1978 & $\begin{array}{c}0.0755 \\
(0.1187)\end{array}$ \\
\hline Top countries x 1979 & $\begin{array}{c}0.1241 \\
(0.1315)\end{array}$ \\
\hline Top countries x 1980 & $\begin{array}{c}0.1732 \\
(0.1207)\end{array}$ \\
\hline Top countries x 1981 & $\begin{array}{c}0.0723 \\
(0.2156)\end{array}$ \\
\hline Top countries x 1982 & $\begin{array}{c}0.0358 \\
(0.2011)\end{array}$ \\
\hline Top countries x 1983 & $\begin{array}{c}0.0176 \\
(0.2237)\end{array}$ \\
\hline Top countries x 1984 & $\begin{array}{c}0.0623 \\
(0.2229)\end{array}$ \\
\hline Top countries x 1985 & $\begin{array}{l}-0.0034 \\
(0.2389)\end{array}$ \\
\hline Top countries x 1986 & $\begin{array}{c}0.0529 \\
(0.2534)\end{array}$ \\
\hline Top countries x 1987 & $\begin{array}{c}-0.0742 \\
(0.2800)\end{array}$ \\
\hline Top countries x 1988 & $\begin{array}{c}0.1295 \\
(0.1702)\end{array}$ \\
\hline Top countries x 1989 & $\begin{array}{c}0.1643 \\
(0.1780)\end{array}$ \\
\hline Top countries x 1990 & $\begin{array}{c}0.1407 \\
(0.1742)\end{array}$ \\
\hline Top countries x 1991 & $\begin{array}{c}0.1387 \\
(0.1751)\end{array}$ \\
\hline Top countries x 1992 & $\begin{array}{l}0.01538 \\
(0.1773)\end{array}$ \\
\hline Top countries x 1993 & $\begin{array}{c}0.1170 \\
(0.1770)\end{array}$ \\
\hline Top countries x 1994 & $\begin{array}{c}0.0961 \\
(0.1789)\end{array}$ \\
\hline Top countries x 1995 & $\begin{array}{c}0.0802 \\
(0.1740)\end{array}$ \\
\hline
\end{tabular}




\begin{tabular}{c|cc}
\hline \multicolumn{3}{c}{ Dependent variable: $\operatorname{Ln}($ Female to male tertiary enrollment) } \\
& $(1)$ & $(2)$ \\
\hline Year dummies & No & Yes \\
Observations & 1,396 & 1,396 \\
\hline
\end{tabular}

Notes: All models are estimated by OLS and include year fixed effects and country fixed effects. Standard errors clustered at the country level are in parentheses. All models include observations with values of Female to male tertiary enrollment larger than 40. Top countries is an indicator variable that takes the value of one for the top 10 countries according to the ratio of the number of soccer players playing in Big Five leagues to the country's population (in 1994). The countries hosting the Big Five leagues are Germany, Italy, Spain, United Kingdom, and France. The Big Five leagues are the German Bundesliga, Italian Serie A, Spanish Liga, English Premier League, and French Ligue 1. ***Significant at 1 percent level. 
Table 3. Main results

\begin{tabular}{c|cc|cc}
\hline \multirow{2}{*}{} & \multicolumn{3}{|c}{ Dependent variable: Ln(Female to male tertiary enrollment) } \\
& All countries & $(2)$ & $(3)$ & Latin America and the Caribbean, \\
& $(1)$ & $0.0178^{* *}$ & $0.0164^{*}$ & $(4)$ \\
\hline $\begin{array}{c}\text { Bosman x Average } \\
\text { players }\end{array}$ & $0.0166^{* *}$ & $(0.0084)$ & $(0.0093)$ & $0.0182^{*}$ \\
\hline Countries hosting the & $(0.0083)$ & No & Yes & No \\
Big Five leagues & Yes & 2,650 & 1,935 & 1,776 \\
Observations & 2,809 & . & $0.0095)$ \\
\hline
\end{tabular}

Notes: All models are estimated by OLS and include year fixed effects and country fixed effects. Standard errors clustered at the country level are in parentheses. All models include observations with values of Female to male tertiary enrollment larger than 40. Models (3) and (4) only include countries from Latin America and the Caribbean, Europe, and Africa. The countries hosting the Big Five leagues are Germany, Italy, Spain, United Kingdom, and France. The Big Five leagues are the German Bundesliga, Italian Serie A, Spanish Liga, English Premier League, and French Ligue 1. *Significant at 10 percent level. **Significant at 5 percent level. 
Table 4. Dependent variable in levels

\begin{tabular}{c|cc|cc}
\hline \multirow{2}{*}{} & \multicolumn{3}{|c}{ Dependent variable: Female to male tertiary enrollment } \\
& All countries & $(2)$ & $(3)$ & Latin America and the Caribbean, \\
& $(1)$ & $2.893^{* *}$ & $2.449^{*}$ & $(4)$ \\
\hline Bosman x Average & $2.778^{* *}$ & $(1.304)$ & $(1.409)$ & $(1.452)$ \\
players & $(1.290)$ & No & Yes & No \\
\hline Countries hosting the & Yes & 2,650 & 1,935 & 1,776 \\
Big Five leagues & 2,809 & Observations & Ond Africa & \\
\hline
\end{tabular}

Notes: All models are estimated by OLS and include year fixed effects and country fixed effects. Standard errors clustered at the country level are in parentheses. All models include observations with values of Female to male tertiary enrollment larger than 40. Models (3) and (4) only include countries from Latin America and the Caribbean, Europe, and Africa. The countries hosting the Big Five leagues are Germany, Italy, Spain, United Kingdom, and France. The Big Five leagues are the German Bundesliga, Italian Serie A, Spanish Liga, English Premier League, and French Ligue 1. *Significant at 10 percent level. **Significant at 5 percent level. 
Table 5. Regional time trends

\begin{tabular}{c|cc|cc}
\hline \multirow{2}{*}{} & \multicolumn{3}{|c}{ Dependent variable: Ln(Female to male tertiary enrollment) } \\
& \multicolumn{2}{|c}{ All countries } & \multicolumn{2}{c}{ Latin America and the Caribbean, } \\
& $(1)$ & $(2)$ & $(3)$ & $(4)$ \\
\hline Bosman x Average & $0.0269^{* * *}$ & $0.0330^{* * * *}$ and Africa & $0.0328^{* * *}$ \\
players & $(0.0085)$ & $(0.0084)$ & $0.0267^{* * *}$ & $(0.0086)$ \\
\hline Regional trends & Yes & Yes & Yes & Yes \\
Countries hosting the & Yes & No & Yes & No \\
Big Five leagues & 2,809 & 2,650 & 1,935 & 1,776 \\
Observations & & &
\end{tabular}

Notes: All models are estimated by OLS and include year fixed effects and country fixed effects. Standard errors clustered at the country level are in parentheses. All models include observations with values of Female to male tertiary enrollment larger than 40. Regional trends are interaction terms between the different regions and a time trend. The regions considered are Latin America, The Caribbean, Europe, Africa, Asia, Pacific and Other regions. Models (3) and (4) only include countries from Latin America and the Caribbean, Europe, and Africa. The countries hosting the Big Five leagues are Germany, Italy, Spain, United Kingdom, and France. The Big Five leagues are the German Bundesliga, Italian Serie A, Spanish Liga, English Premier League, and French Ligue 1. ***Significant at 1 percent level. 
Table 6. Alternative measure of exposure to the Bosman ruling

\begin{tabular}{|c|c|c|c|c|}
\hline & \multicolumn{4}{|c|}{ Dependent variable: Female to male tertiary enrollment } \\
\hline & \multicolumn{2}{|c|}{ All countries } & \multicolumn{2}{|c|}{$\begin{array}{c}\text { Latin America and the Caribbean, } \\
\text { Europe, and Africa }\end{array}$} \\
\hline & (1) & (2) & (3) & (4) \\
\hline $\begin{array}{l}\text { Bosman x Top } \\
\text { countries }\end{array}$ & $\begin{array}{l}0.0821^{*} \\
(0.0484)\end{array}$ & $\begin{array}{l}0.0870^{*} \\
(0.0488)\end{array}$ & $\begin{array}{c}0.0812 \\
(0.0519)\end{array}$ & $\begin{array}{l}0.0884^{*} \\
(0.0530)\end{array}$ \\
\hline $\begin{array}{l}\text { Countries hosting the } \\
\text { Big Five leagues }\end{array}$ & Yes & No & Yes & No \\
\hline Observations & 2,809 & 2,650 & 1,935 & 1,776 \\
\hline
\end{tabular}

Notes: All models are estimated by OLS and include year fixed effects and country fixed effects. Standard errors clustered at the country level are in parentheses. All models include observations with values of Female to male tertiary enrollment larger than 40. Models (3) and (4) only include countries from Latin America and the Caribbean, Europe, and Africa. Top countries is an indicator variable that takes the value of one for the top 10 countries according to the ratio of the number of soccer players playing in Big Five leagues to the country's population (in 1994). The countries hosting the Big Five leagues are Germany, Italy, Spain, United Kingdom, and France. The Big Five leagues are the German Bundesliga, Italian Serie A, Spanish Liga, English Premier League, and French Ligue 1. *Significant at 10 percent level. 
Table 7. Placebo test

\begin{tabular}{c|cc}
\hline \multicolumn{2}{c}{ Dependent variable: Ln(Female to male tertiary enrollment) } \\
& $\begin{array}{c}\text { Unexposed } \\
\text { countries } \\
(1)\end{array}$ & $\begin{array}{c}\text { Exposed } \\
\text { countries } \\
(2)\end{array}$ \\
\hline Bosman & 0.0106 & \\
Bosman x Average players & $(0.0449)$ & $0.0194 * * *$ \\
Time trend & & $(0.0070)$ \\
& $0.0196 * * *$ & $0.0188^{* * *}$ \\
Observations & $(0.0023)$ & $(0.0012)$ \\
\hline
\end{tabular}

Notes: All models are estimated by OLS and include year fixed effects and country fixed effects. Standard errors clustered at the country level are in parentheses. All models include observations with values of Female to male tertiary enrollment larger than 40. Model (1) considers only countries with countries with no players in the Big Five leagues in 1994. Model (2) considers only countries with positive values of Average players. ${ }^{*} * *$ Significant at 1 percent level. 


\section{Table 8. Male and female enrollment}

\begin{tabular}{|c|c|c|c|c|}
\hline & \multicolumn{4}{|c|}{ Panel A - Dependent variable: Ln(Male tertiary enrollment) } \\
\hline & \multicolumn{2}{|c|}{ All countries } & \multicolumn{2}{|c|}{$\begin{array}{c}\text { Latin America and the Caribbean, } \\
\text { Europe, and Africa }\end{array}$} \\
\hline & $(1)$ & $(2)$ & $(3)$ & $(4)$ \\
\hline $\begin{array}{c}\text { Bosman x Average } \\
\text { players }\end{array}$ & $\begin{array}{l}-0.0310 \\
(0.0202)\end{array}$ & $\begin{array}{l}-0.354 * \\
(0.0212)\end{array}$ & $\begin{array}{l}-0.0282 \\
(0.0201)\end{array}$ & $\begin{array}{l}-0.0352 * \\
(0.0216)\end{array}$ \\
\hline \multirow[t]{4}{*}{$\begin{array}{c}\text { Countries hosting the } \\
\text { Big Five leagues } \\
\text { Observations }\end{array}$} & $\begin{array}{c}\text { Yes } \\
2,809 \\
\end{array}$ & $\begin{array}{r}\text { No } \\
2,650 \\
\end{array}$ & $\begin{array}{c}\text { Yes } \\
1,935 \\
\end{array}$ & $\begin{array}{c}\text { No } \\
1,776 \\
\end{array}$ \\
\hline & \multicolumn{4}{|c|}{ Panel B - Dependent variable: Ln(Female tertiary enrollment) } \\
\hline & \multicolumn{2}{|c|}{ All countries } & \multicolumn{2}{|c|}{$\begin{array}{c}\text { Latin America and the Caribbean, } \\
\text { Europe, and Africa }\end{array}$} \\
\hline & $(5)$ & $(6)$ & $(7)$ & $(8)$ \\
\hline $\begin{array}{c}\text { Bosman x Average } \\
\text { Players }\end{array}$ & $\begin{array}{l}-0.0144 \\
(0.0212)\end{array}$ & $\begin{array}{l}-0.0176 \\
(0.0221)\end{array}$ & $\begin{array}{l}-0.0119 \\
(0.0208)\end{array}$ & $\begin{array}{l}-0.0170 \\
(0.0222)\end{array}$ \\
\hline $\begin{array}{l}\text { Countries hosting the } \\
\text { Big Five leagues }\end{array}$ & Yes & No & Yes & No \\
\hline Observations & 2,809 & 2,650 & 1,935 & 1,776 \\
\hline
\end{tabular}

Notes: All models are estimated by OLS and include year fixed effects and country fixed effects. Standard errors clustered at the country level are in parentheses. All models include observations with values of Female to male tertiary enrollment larger than 40. Models (3), (4), (7) and (8) only include countries from Latin America and the Caribbean, Europe, and Africa. The countries hosting the Big Five leagues are Germany, Italy, Spain, United Kingdom, and France. The Big Five leagues are the German Bundesliga, Italian Serie A, Spanish Liga, English Premier League, and French Ligue 1. *Significant at 10 percent level. 
Table B1. List of countries by the number of soccer players in Big Five soccer leagues in the 1994/95 season (per 1,000,000 inhabitants)

\begin{tabular}{|c|c|}
\hline Country & $\begin{array}{c}\text { Players in Big Five } \\
\text { leagues in } 1994\end{array}$ \\
\hline Iceland & 7.5 \\
\hline Ireland & 6.7 \\
\hline Croatia & 3.9 \\
\hline Denmark & 3.8 \\
\hline Luxembourg & 3.2 \\
\hline Liberia & 2.5 \\
\hline Jamaica & 2.4 \\
\hline Equatorial Guinea & 2.3 \\
\hline Norway & 2.1 \\
\hline Uruguay & 1.9 \\
\hline Netherlands & 1.6 \\
\hline Trinidad and Tobago & 1.6 \\
\hline Sweden & 1.5 \\
\hline Bulgaria & 1.1 \\
\hline Slovak Republic & 1.1 \\
\hline Switzerland & 1.1 \\
\hline Macedonia, FYR & 1.0 \\
\hline Czech Republic & 1.0 \\
\hline Guinea & 0.9 \\
\hline Cameroon & 0.8 \\
\hline Portugal & 0.6 \\
\hline New Zealand & 0.6 \\
\hline Romania & 0.5 \\
\hline Argentina & 0.5 \\
\hline Ghana & 0.5 \\
\hline Austria & 0.5 \\
\hline Slovenia & 0.5 \\
\hline Australia & 0.5 \\
\hline Benin & 0.4 \\
\hline Poland & 0.4 \\
\hline Panama & 0.4 \\
\hline Belgium & 0.3 \\
\hline Senegal & 0.3 \\
\hline Albania & 0.3 \\
\hline Tunisia & 0.3 \\
\hline Lithuania & 0.3 \\
\hline Moldova & 0.3 \\
\hline
\end{tabular}




\begin{tabular}{|c|c|}
\hline Country & $\begin{array}{c}\text { Players in Big Five } \\
\text { leagues in } 1994\end{array}$ \\
\hline Togo & 0.2 \\
\hline Georgia & 0.2 \\
\hline Chad & 0.2 \\
\hline Israel & 0.2 \\
\hline Cote d'Ivoire & 0.2 \\
\hline Zimbabwe & 0.2 \\
\hline France & 0.2 \\
\hline Colombia & 0.1 \\
\hline Hungary & 0.1 \\
\hline Nigeria & 0.1 \\
\hline Russian Federation & 0.1 \\
\hline Canada & 0.1 \\
\hline Greece & 0.1 \\
\hline Congo, Dem. Rep. & 0.1 \\
\hline Morocco & 0.1 \\
\hline Angola & 0.1 \\
\hline Chile & 0.1 \\
\hline Germany & 0.1 \\
\hline United Kingdom & 0.1 \\
\hline Spain & 0.1 \\
\hline Peru & 0.0 \\
\hline United States & 0.0 \\
\hline Ukraine & 0.0 \\
\hline Italy & 0.0 \\
\hline Turkey & 0.0 \\
\hline Egypt, Arab Rep. & 0.0 \\
\hline Japan & 0.0 \\
\hline Azerbaijan & 0.0 \\
\hline Bahrain & 0.0 \\
\hline Bangladesh & 0.0 \\
\hline Barbados & 0.0 \\
\hline Belize & 0.0 \\
\hline Bermuda & 0.0 \\
\hline Bhutan & 0.0 \\
\hline Botswana & 0.0 \\
\hline Brunei Darussalam & 0.0 \\
\hline Burkina Faso & 0.0 \\
\hline Burundi & 0.0 \\
\hline Cambodia & 0.0 \\
\hline
\end{tabular}




\begin{tabular}{|c|c|}
\hline Country & $\begin{array}{c}\text { Players in Big Five } \\
\text { leagues in } 1994\end{array}$ \\
\hline Central African Republic & 0.0 \\
\hline China & 0.0 \\
\hline Comoros & 0.0 \\
\hline Congo, Rep. & 0.0 \\
\hline Costa Rica & 0.0 \\
\hline Cuba & 0.0 \\
\hline Cyprus & 0.0 \\
\hline Dominican Republic & 0.0 \\
\hline Ecuador & 0.0 \\
\hline El Salvador & 0.0 \\
\hline Eritrea & 0.0 \\
\hline Estonia & 0.0 \\
\hline Ethiopia & 0.0 \\
\hline Fiji & 0.0 \\
\hline Finland & 0.0 \\
\hline Gabon & 0.0 \\
\hline Gambia, The & 0.0 \\
\hline Guatemala & 0.0 \\
\hline Honduras & 0.0 \\
\hline Hong Kong SAR, China & 0.0 \\
\hline India & 0.0 \\
\hline Indonesia & 0.0 \\
\hline Iran, Islamic Rep. & 0.0 \\
\hline Iraq & 0.0 \\
\hline Jordan & 0.0 \\
\hline Kazakhstan & 0.0 \\
\hline Kenya & 0.0 \\
\hline Korea, Rep. & 0.0 \\
\hline Kuwait & 0.0 \\
\hline Kyrgyz Republic & 0.0 \\
\hline Lao PDR & 0.0 \\
\hline Latvia & 0.0 \\
\hline Lebanon & 0.0 \\
\hline Lesotho & 0.0 \\
\hline Libya & 0.0 \\
\hline Macao SAR, China & 0.0 \\
\hline Malawi & 0.0 \\
\hline Malaysia & 0.0 \\
\hline Mali & 0.0 \\
\hline
\end{tabular}




\begin{tabular}{|c|c|}
\hline Country & $\begin{array}{c}\text { Players in Big Five } \\
\text { leagues in } 1994\end{array}$ \\
\hline Malta & 0.0 \\
\hline Mauritania & 0.0 \\
\hline Mauritius & 0.0 \\
\hline Mexico & 0.0 \\
\hline Mozambique & 0.0 \\
\hline Myanmar & 0.0 \\
\hline Namibia & 0.0 \\
\hline Nepal & 0.0 \\
\hline Nicaragua & 0.0 \\
\hline Niger & 0.0 \\
\hline Oman & 0.0 \\
\hline Pakistan & 0.0 \\
\hline Papua New Guinea & 0.0 \\
\hline Paraguay & 0.0 \\
\hline Philippines & 0.0 \\
\hline Rwanda & 0.0 \\
\hline Samoa & 0.0 \\
\hline Saudi Arabia & 0.0 \\
\hline Sierra Leone & 0.0 \\
\hline Sri Lanka & 0.0 \\
\hline St. Lucia & 0.0 \\
\hline Suriname & 0.0 \\
\hline Swaziland & 0.0 \\
\hline Syrian Arab Republic & 0.0 \\
\hline Tanzania & 0.0 \\
\hline Thailand & 0.0 \\
\hline Tonga & 0.0 \\
\hline Uganda & 0.0 \\
\hline Venezuela, RB & 0.0 \\
\hline Vietnam & 0.0 \\
\hline Yemen, Rep. & 0.0 \\
\hline Zambia & 0.0 \\
\hline
\end{tabular}

Notes: The total number of players in the 1994/95 season in Big Five leagues by country was obtained from the website of Transfermarkt $\mathrm{GmbH}$ \& Co. KG (http://www.transfermarkt.com/). Population data were obtained from the World Bank's World Development Indicators. 
Figure 1. Evolution of the ratio of female to male tertiary enrollment

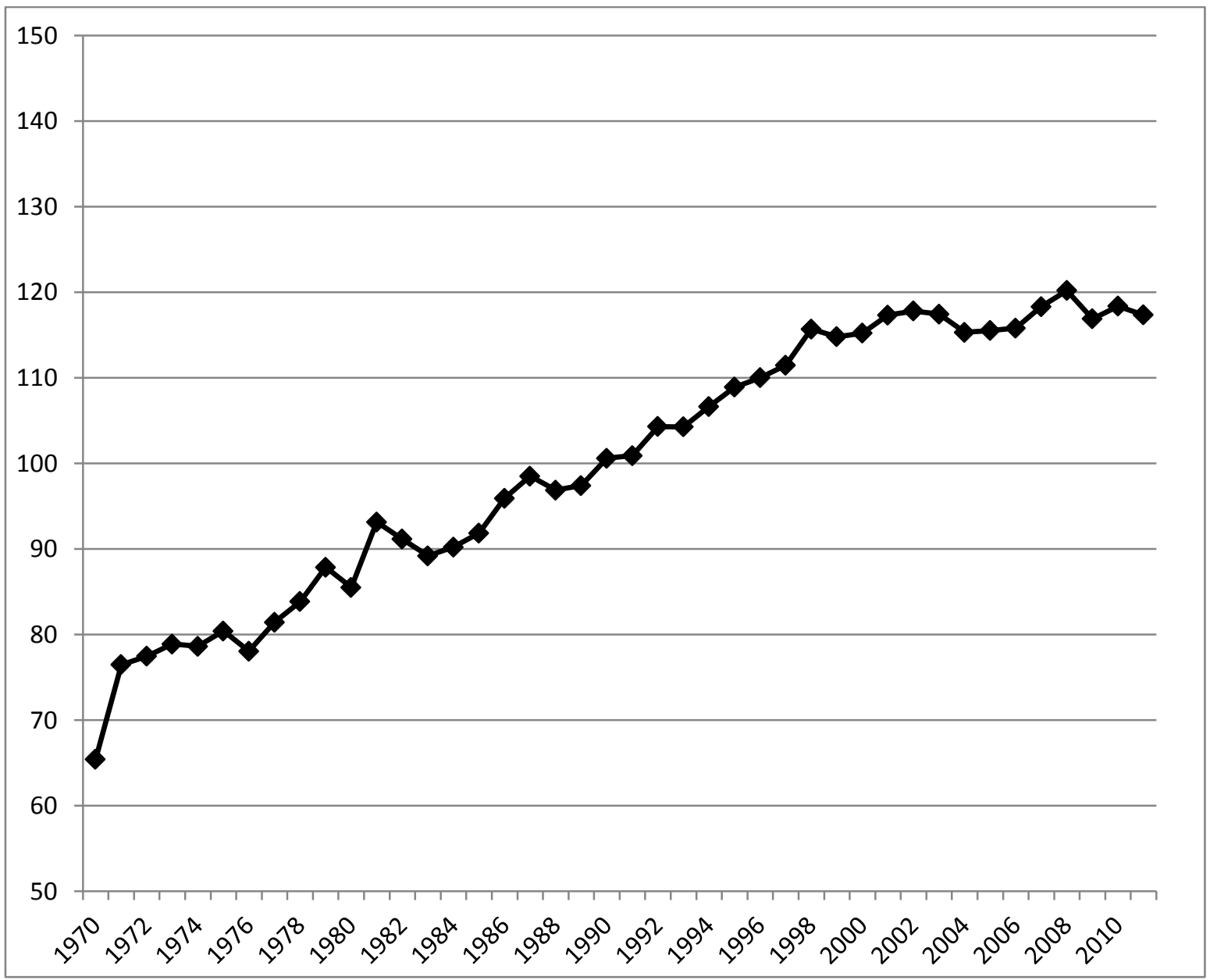

Note: The data corresponds to the yearly average ratio of female to male tertiary enrollment. 
Figure 2. Evolution of the ratio of the average weekly salary of professional baseball players to the average weekly salary of production workers in the US

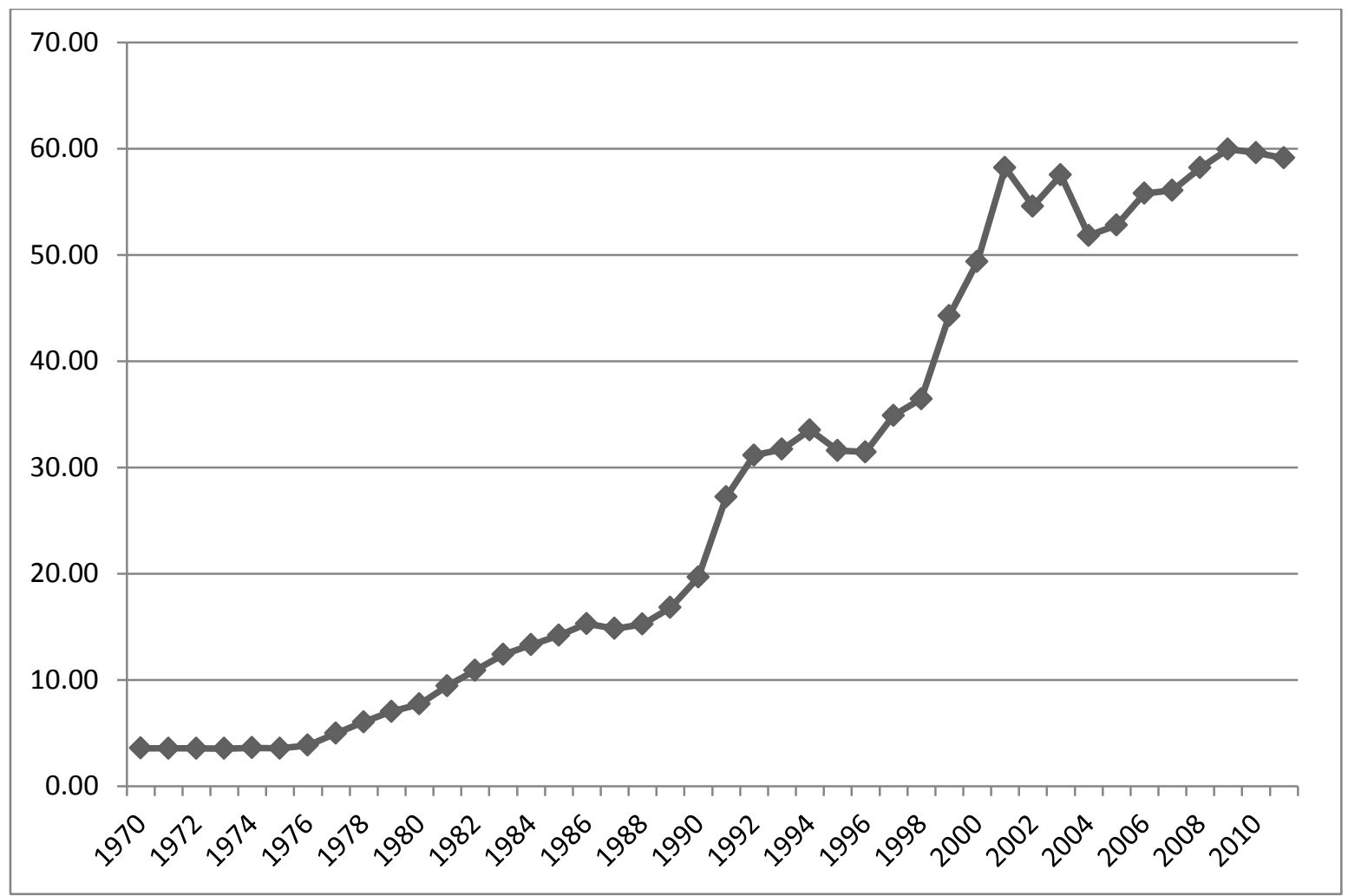

Notes: The series on average weekly salaries of professional baseball players (MLB) was built from annual data obtained through the websites of the Economic History Association (http://eh.net/encyclopedia/theeconomic-history-of-major-league-baseball/) and USA Today (http://content.usatoday.com/sportsdata/baseball/ mlb/salaries/team/), and dividing it by 52 . The series on weekly salaries of production (blue-collar, hourly rated workers, or nonoffice) workers was built by multiplying data on hourly wages obtained from http://www.measuringworth.com/uswage/ by 40 . 
Figure 3. Salaries in the Big Five soccer leagues before and after the Bosman ruling

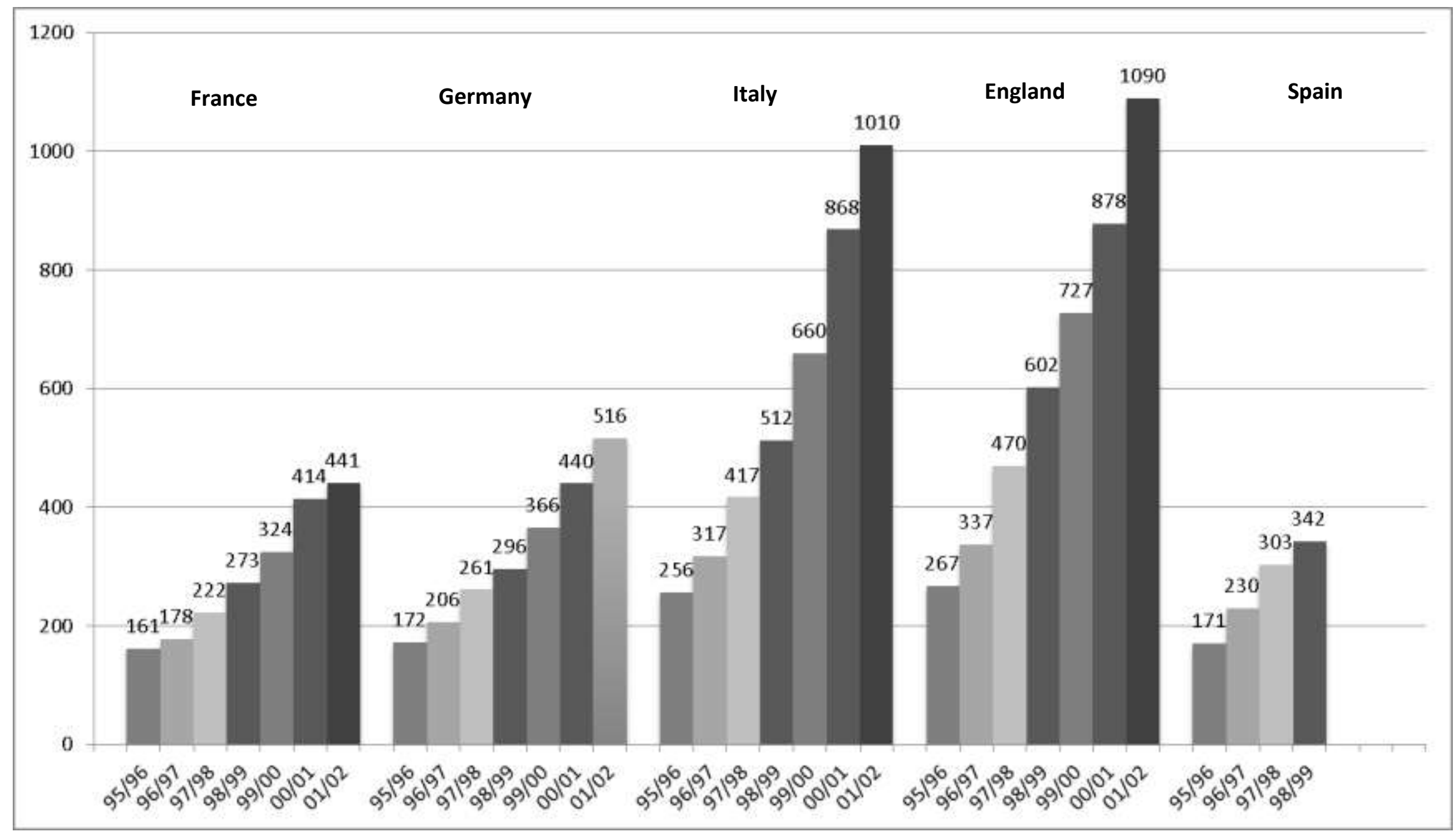

Notes: Data on gross salary expenditure (in millions of euros) by league and season were obtained from various issues of Deloitte's Annual Review of Football Finance. The horizontal axis displays soccer seasons in Europe. The Big Five leagues are the German Bundesliga, Italian Serie A, Spanish Liga, English Premier League, and French Ligue 1. 


\section{Figure 4. Evolution of the number of foreign players in Big Five soccer leagues before and after the Bosman ruling}

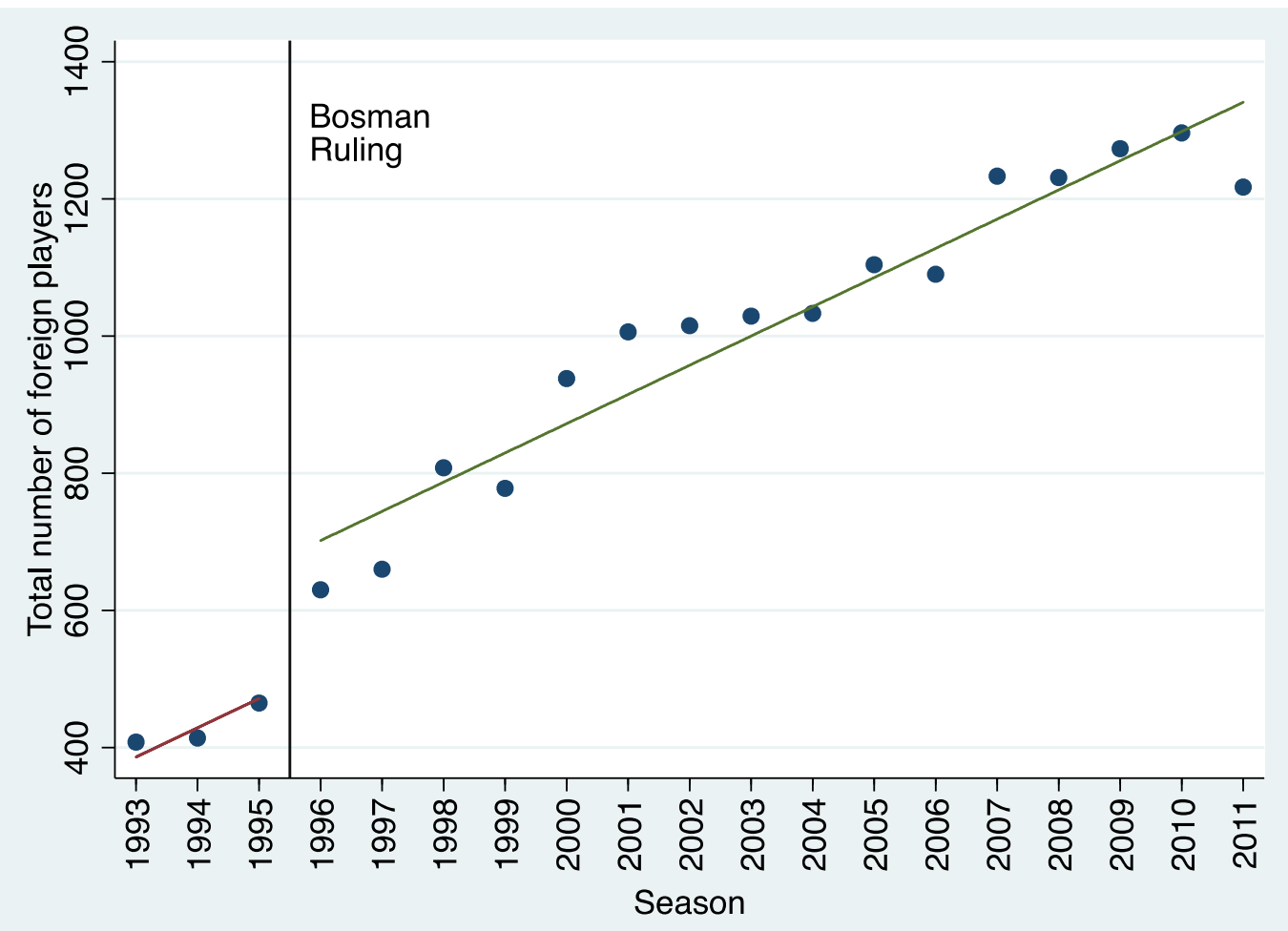

Notes: The data points correspond to the total number of foreign players by year in the Big Five leagues, and were taken mostly from the website of Transfermarkt GmbH \& Co. KG (http://www.transfermarkt.com/). Data for France in 1993-96 and Spain in 1993 and 1995 were estimated using data from Transfermarkt and http://www.national-football-teams.com/. The fitted lines through the data points are obtained from an OLS regression of the total number of foreign players on a time trend and a dummy variable that takes value 1 after the Bosman ruling (significantly different from zero at the 1 percent level). 
Figure 5. Countries by the number of soccer players in Big Five soccer leagues in the 1994/95 season (per 1,000,000 inhabitants)

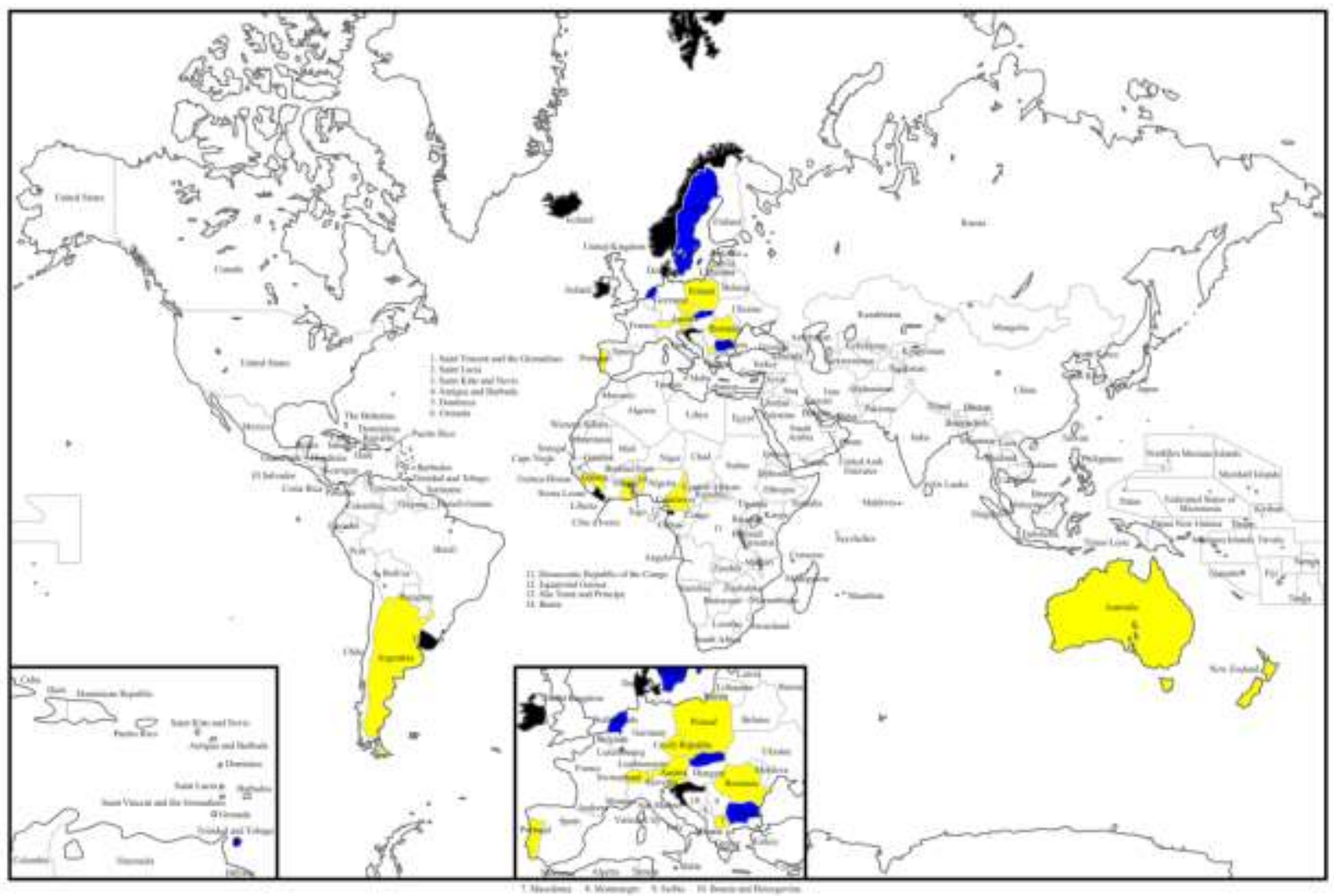

Notes: The total number of players in the 1994/95 season in Big Five leagues by country was obtained from the website of Transfermarkt GmbH \& Co. KG (http://www.transfermarkt.com/). Population data were obtained from the World Bank's World Development Indicators. The figure uses the following color code according to the countries' ranking by number of players in Big Five soccer leagues per 1,000,000 inhabitants 1994: black (top 10), blue (top 15), and yellow (top 30). 
Figure 6. Evolution of the ratio of female to male tertiary enrollment according to the countries' exposure to the Bosman ruling

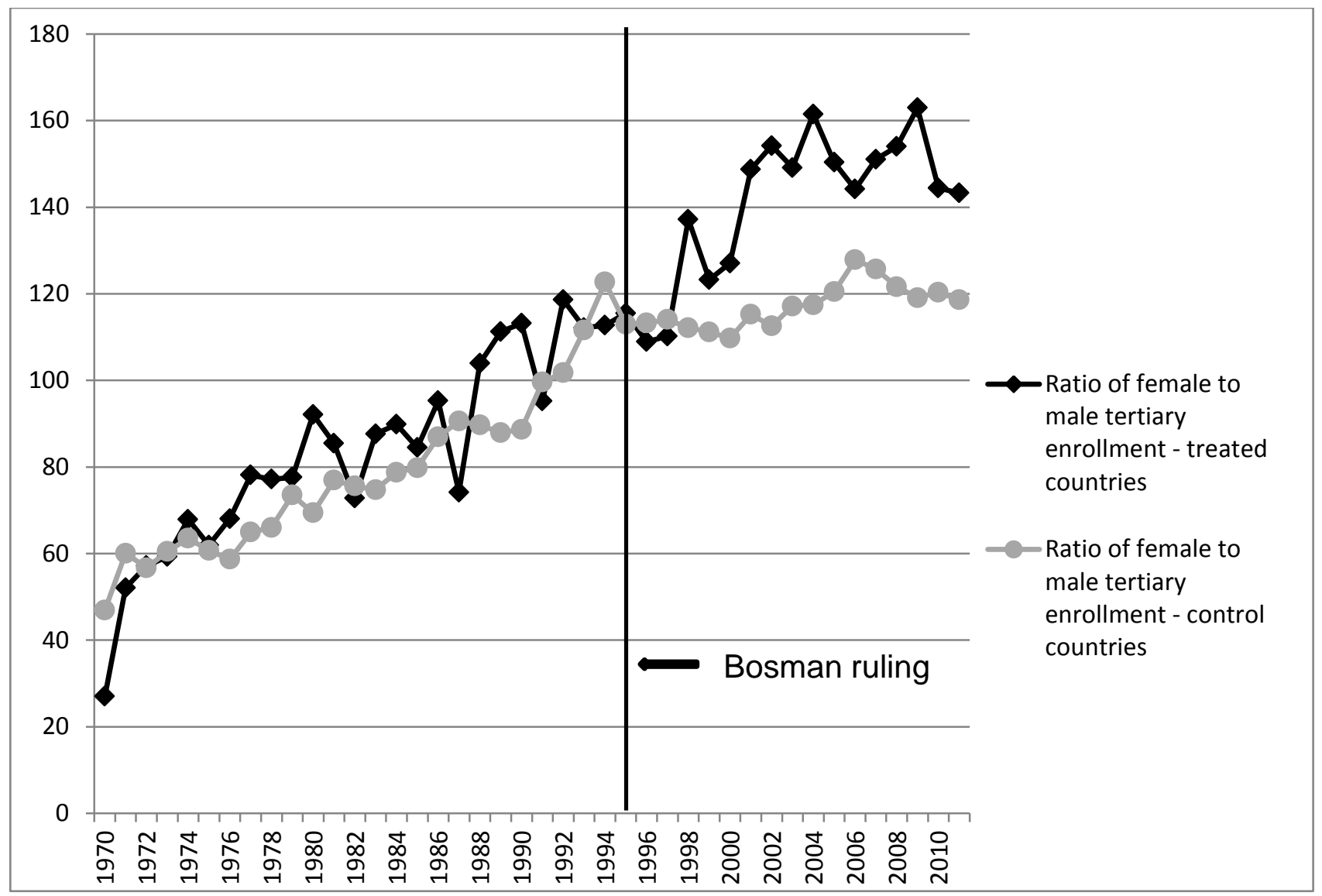

Notes: The figure considers countries in which the ratio of female to male tertiary enrollment in 1994 was above the mean ratio for the full sample in that year. The treated group in the figure includes the top 10 countries according to the ratio of the number of soccer players in Big Five leagues to the country's population, in 1994. The Big Five leagues are the German Bundesliga, Italian Serie A, Spanish Liga, English Premier League, and French Ligue 1. 